\title{
Mechanistic Studies on the Reaction of Nitroxylcobalamin with Dioxygen: Evidence for Formation of a Peroxynitritocob(III)alamin Intermediate
}

\author{
Harishchandra Subedi ${ }^{\dagger}$ and Nicola E. Brasch ${ }^{* \dagger \dagger} \dagger$ \\ ${ }^{\dagger}$ Department of Chemistry and Biochemistry and ${ }^{\ddagger}$ School of Biomedical Sciences, Kent State University, Kent, Ohio 44242, United \\ States
}

Supporting Information

\begin{abstract}
Studies by others suggest that the reduced vitamin $\mathrm{B}_{12}$ complex, $\operatorname{cob}(\mathrm{II})$ alamin, scavenges nitric oxide to form air-sensitive nitroxylcobalamin $\left(\mathrm{NO}^{-}\right.$$\mathrm{Cbl}(\mathrm{III})$; NOCbl) in vivo. The fate of newly formed NOCbl is not known. A detailed mechanistic investigation of the oxidation of NOCbl by oxygen is presented. Only base-on NOCbl reacts with $\mathrm{O}_{2}$, and the reaction proceeds via an associative mechanism involving a peroxynitritocob(III)alamin intermediate, $\mathrm{Co}(\mathrm{III})-\mathrm{N}(\mathrm{O}) \mathrm{OO}^{-}$. The intermediate undergoes $\mathrm{O}-\mathrm{O}$ bond homolysis and ligand isomerization to ultimately yield $\mathrm{NO}_{2} \mathrm{Cbl}$ and $\mathrm{H}_{2} \mathrm{OCbl}^{+} / \mathrm{HOCbl}$, respectively. Ligand isomerization may potentially occur independent of $\mathrm{O}-\mathrm{O}$ bond homolysis. Formation of ${ }^{\bullet} \mathrm{OH}$ and ${ }^{-} \mathrm{NO}_{2}$ intermediates from $\mathrm{O}-\mathrm{O}$ bond homolysis is demonstrated using phenol and tyrosine radical traps and the characterization of small amounts of a corrinoid product with minor modifications to the corrin ring.
\end{abstract}

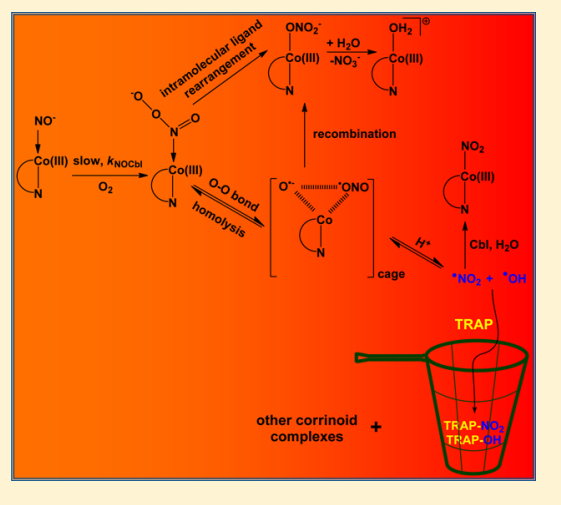

\section{INTRODUCTION}

Nitric oxide $\left({ }^{\circ} \mathrm{NO}, \mathrm{NO}\right)$ is an important cellular signaling molecule produced in cells by nitric oxide synthases (NOS). ${ }^{1}$ $\mathrm{NO}$ is involved in physiological and pathological processes in mammals, playing a key role in vasodilation, the immune response, neurotransmission, and inhibiting platelet aggregation. ${ }^{2,3}$ Vitamin $B_{12}$ derivatives (cobalamins, Cbls) are a class of cobalt-containing macrocyclic complexes synthesized by bacteria which are structurally close to porphyrins, Figure 1. The $\mathrm{Co}^{3+} \mathrm{NO}^{-}$derivative of vitamin $\mathrm{B}_{12}$ known as nitrosylcobalamin or nitroxylcobalamin, $\mathrm{NO}^{-}-\mathrm{Cbl}(\mathrm{III}),{ }^{4}$ has attracted considerable attention in literature. Both mammalian $\mathrm{B}_{12}$-dependent enzymes, methylcobalamin-dependent methionine synthase, and adenosylcobalamin-dependent L-methylmalonyl-CoA mutase, are inhibited by NO in vitro and in vivo, ${ }^{5,6}$ and the inhibition is attributed to the formation of NOCbl. ${ }^{7}$ It has been postulated that cobalamins efficiently scavenge $\mathrm{NO}$ in vivo to form $\mathrm{NOCbl}^{7,8} \mathrm{Cob}(\mathrm{II})$ alamin, a major intracellular form of $\mathrm{Cbl},{ }^{9}$ reacts with $\mathrm{NO}$ at almost diffusion controlled rates to form NOCbl $\left(k=7.4 \times 10^{8} \mathrm{M}^{-1} \mathrm{~s}^{-1}, K_{\mathrm{eq}} \approx 1 \times 10^{8}\right.$ $\left.\mathrm{M}^{-1}, 25^{\circ} \mathrm{C}\right) .{ }^{10,11}$ Cbls show potential in treating pathologies associated with elevated NO levels including sepsis/septic shock. ${ }^{8,12} \mathrm{Cbls}$ also inhibit NO-induced vasodilation ${ }^{13}$ and NOinduced smooth muscle relaxation. ${ }^{14,15}$ Finally, it has been proposed that NOCbl can act as a chemotherapeutic agent to treat cancer. ${ }^{16}$

NOCbl itself is extremely air sensitive. ${ }^{10,17,18}$ Interestingly, others choose not to report this fact when discussing the biological relevance of the trapping of $\mathrm{NO}$ by $\mathrm{Cbl}$ to form $\mathrm{NOCbl}$, or in studies focused on therapeutic properties of

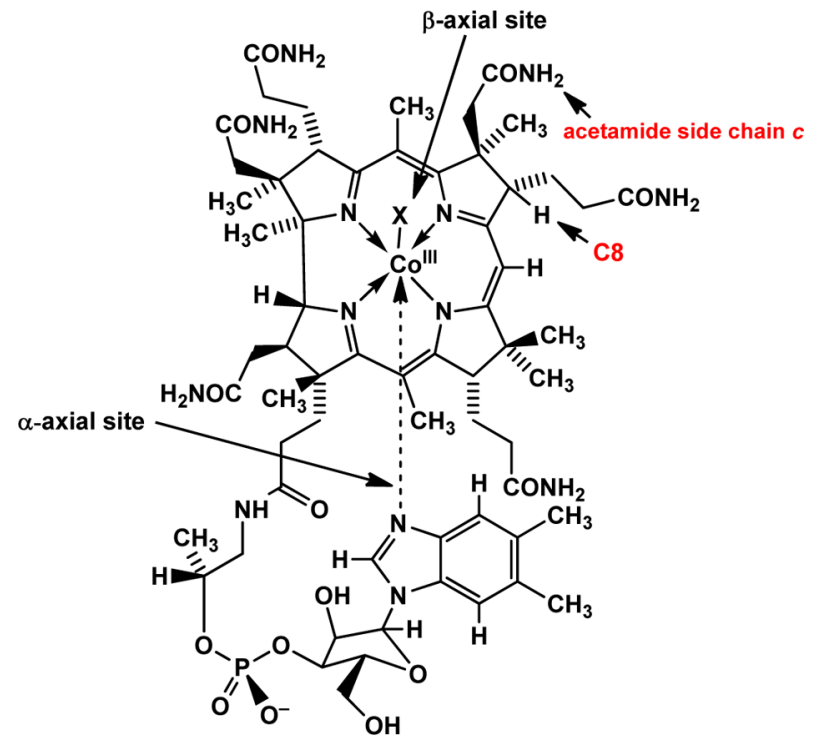

Figure 1. Structure of vitamin $\mathrm{B}_{12}$ (cobalamins): $\mathrm{X}=\mathrm{CN}^{-}, \mathrm{CH}_{3}$, Ado, $\mathrm{H}_{2} \mathrm{O}, \mathrm{NO}^{-}, \mathrm{NO}_{2}^{-}$, etc.

NOCbl. ${ }^{6,7,13,14,19-21}$ Furthermore, although UV-vis spectral studies reported by us and others suggest that NOCbl is simply oxidized to nitrocobalamin $\left(\mathrm{NO}_{2} \mathrm{Cbl}\right)$ by $\mathrm{O}_{2}$ (although this is not so simple as it initially seems, since it requires cleavage of the $\mathrm{O}=\mathrm{O}$ bond), ${ }^{10,17,18,22}$ studies by others on the reactions of

Received: July 30, 2013

Published: September 19, 2013 
other $\mathrm{NO}^{-}-\mathrm{Co}(\mathrm{III})$ complexes with $\mathrm{O}_{2}$ suggest that the mechanism is complex, with multiple products produced under some conditions. ${ }^{23}$ Herein, we present a detailed mechanistic study of the reaction between $\mathrm{NOCbl}$ and $\mathrm{O}_{2}$, which provides support for formation of a peroxynitrito $\mathrm{Co}$ (III) intermediate.

\section{EXPERIMENTAL SECTION}

Materials and Methods. Chemicals. Hydroxycobalamin hydrochloride ( $\mathrm{HOCbl} \cdot \mathrm{HCl}, 98 \%$ stated purity by the manufacturer) was purchased from Fluka. All biological buffers (MES, TES, TAPS, and CAPS $)$ and inorganic buffers $\left(\mathrm{CH}_{3} \mathrm{COONa}, \mathrm{NaH}_{2} \mathrm{PO}_{4}\right.$, or $\left.\mathrm{Na}_{2} \mathrm{HPO}_{4}\right)$, $\mathrm{D}_{2} \mathrm{O}$ (99.8 atom \% D), KCN (99\%), acetone, glacial acetic acid (HPLC grade), triflic acid, ammonium hydroxide, $\mathrm{NaOH}$, phenol ( $\geq 99 \%)$, catechol (99\%), 2-nitrophenol (99\%), 4-nitrophenol (98\%), $L$-tyrosine $(\geq 99 \%)$, $n$-octylamine $(\geq 99 \%)$, tetrabutylammonium hydrogen sulfate $(99 \%)$, sodium nitrate $(\geq 99 \%)$, sodium dithionite $(85 \%)$, and HPLC grade water and acetonitrile were purchased from either Fisher Scientific or Acros Organics. Hydroquinone ( $\geq 99 \%)$, 3,4dihydroxy-L-phenylalanine ( $\geq 98 \%)$, 3-nitro- $L$-tyrosine ( $\geq 98 \%)$, TSP (3-(trimethylsilyl)propionic 2,2,3,3- $d_{4}$ acid, sodium salt) and methanol (HPLC grade) were obtained from Sigma Aldrich. 2- $(\mathrm{N}, \mathrm{N}$ diethylamino)-diazenolate 2-oxide (DEA-NONOate, $\mathrm{Na}^{+}$salt, $\geq 98 \%$ ) was purchased from Cayman Chemical. Water was purified using a Barnstead Nanopure Diamond water purification system.

Synthesis of NOCbl. NOCbl was prepared under anaerobic conditions inside the glovebox using a published procedure. ${ }^{18}$ The formation of NOCbl product was confirmed by ${ }^{1} \mathrm{H}$ NMR and UV-vis spectroscopy.

Synthesis of $\mathrm{NO}_{2} \mathrm{Cbl}$. $\mathrm{NO}_{2} \mathrm{Cbl}$ was prepared following a procedure reported in the literature. ${ }^{22}{ }^{1} \mathrm{H}$ NMR and UV-vis spectroscopy were used to characterize $\mathrm{NO}_{2} \mathrm{Cbl}$ and check its purity.

General Methods. Solution Preparations. All solutions were prepared using standard biological buffers and inorganic buffers (acetate and phosphate; $0.10 \mathrm{M}$ ) and a constant ionic strength was maintained using sodium triflate $\left(\mathrm{NaCF}_{3} \mathrm{SO}_{3} ; I=1.0 \mathrm{M}\right)$. Air-saturated solutions were prepared by bubbling air through the solutions for at least $\sim 6 \mathrm{~h}$. Air-free solutions were prepared by bubbling argon for $\sim 24$ h. Air-sensitive solutions were stored in the MBRAUN Labmaster 130 $(1250 / 78)$ glovebox filled with argon, equipped with $\mathrm{O}_{2}$ and $\mathrm{H}_{2} \mathrm{O}$ sensors and a freezer at $-24{ }^{\circ} \mathrm{C}$. Solutions of varying oxygen concentration were prepared by mixing air-saturated buffer solution $\left(\left[\mathrm{O}_{2}\right]=1.22 \times 10^{-3} \mathrm{M}\right.$ at $\left.25^{\circ} \mathrm{C}^{24}\right)$ and deoxygenated buffer solution in different proportions.

Determination of $\mathrm{Cb}$ Concentrations. The percentage of water in $\mathrm{HOCbl} \cdot \mathrm{HCl}\left(\cdot n \mathrm{H}_{2} \mathrm{O}\right)$ was determined by converting $\mathrm{HOCbl} \cdot \mathrm{HCl}$ to dicyanocobalamin, $(\mathrm{CN})_{2} \mathrm{Cbl}^{-}\left(0.10 \mathrm{M} \mathrm{KCN}, \mathrm{pH} 11.0, \varepsilon_{368 \mathrm{~nm}}=3.04\right.$ $\left.\times 10^{4} \mathrm{M}^{-1} \mathrm{~cm}^{-1}\right) .{ }^{25}$ NOCbl concentrations in stock solutions were determined using the same procedure. Alternatively, concentrations were determined by UV-vis spectrometry (extinction coefficient for $\mathrm{NOCbl}$ at $\left.478 \mathrm{~nm}, \varepsilon_{478 \mathrm{~nm}}=6.91 \times 10^{3} \mathrm{M}^{-1} \mathrm{~cm}^{-1}\right){ }^{18}$

$\mathrm{pH}$ Measurements. All $\mathrm{pH}$ measurements were carried out at room temperature using an Orion Model 710A pH meter equipped with a Mettler-Toledo Inlab 423 or 421 electrodes. The electrode was filled with $3 \mathrm{M} \mathrm{KCl} /$ saturated $\mathrm{AgCl}$ solution $(\mathrm{pH} 7)$ and calibrated with standard buffer solutions at $\mathrm{pH} 4.00,7.00,10.00$, and 12.45 .

Kinetic Experiments. Air-free UV-vis spectrometric measurements were carried out in Schlenk cuvettes (cuvettes fitted with a J-Young or an equivalent stopcock) on a Cary 5000 spectrophotometer equipped with a thermostatted $\left(25.0 \pm 0.1{ }^{\circ} \mathrm{C}\right)$ cell changer operating with WinUV Bio software (version 3.00). Freshly prepared solutions were used for kinetic measurements. For rapid reactions, kinetic data were collected under strictly anaerobic conditions at $25.0 \pm 0.2{ }^{\circ} \mathrm{C}$ using an Applied Photophysics SX20 stopped-flow instrument equipped with a photodiode array detector, operating with Pro-Data SX (version 2.1.4) and Pro-Data Viewer (version 4.1.10) software, with either a 2 or a 10 $\mathrm{mm}$ path length cell. The instrument was continuously purged with nitrogen gas during data collection and pretreated with aqueous anaerobic sodium dithionite $\left(5 \times 10^{-3} \mathrm{M}\right)$ to remove oxygen for at least $1 \mathrm{~h}$ prior to thoroughly washing with anaerobic water. Hamilton gastight syringes filled with the anaerobic reactant solutions in the glovebox were used to introduce the reactant solutions into the reservoir syringes of the stopped-flow instrument. Data were fitted using the program Microcal Origin version 8.0.

${ }^{1} \mathrm{H}$ NMR Measurements. ${ }^{1} \mathrm{H}$ NMR spectra were recorded on a Bruker $400 \mathrm{MHz}$ spectrometer equipped with a $5 \mathrm{~mm}$ probe at $23 \pm 1$ ${ }^{\circ} \mathrm{C}$. TSP was used as internal reference. For ${ }^{1} \mathrm{H}$ NMR experiments under anaerobic conditions, airtight J-Young NMR tubes (Wilmad, 535-JY-7) were used. Reaction mixtures were equilibrated for $15 \mathrm{~min}$ prior to measurements.

HPLC Experiments. HPLC analyses were carried out in an Agilent 1100 series HPLC system equipped with a degasser, quaternary pump, autosampler, and a photodiode array detector (resolution of $2 \mathrm{~nm}$ ).

Method A. A Phenomenex Luna $\mathrm{C}_{18}$ semipreparative column (5 $\mu \mathrm{m}, 100 \AA, 10 \mathrm{~mm} \times 250 \mathrm{~mm}$ ) was used. Peaks were monitored at 254, 280, and $350 \mathrm{~nm}$ and a mobile phase consisting of acetic acid buffer $\left(0.1 \% \mathrm{v} / \mathrm{v}\right.$ in $\mathrm{H}_{2} \mathrm{O}, \mathrm{pH}$ adjusted to 4.0 with $\left.4.0 \mathrm{~N} \mathrm{NH}_{4} \mathrm{OH}\right), \mathbf{A}$, and $0.1 \%$ acetic acid (v/v) in pure $\mathrm{CH}_{3} \mathrm{CN}$ (pH not adjusted), B was used. Gradient conditions: 0-2 $\mathrm{min}, 95: 5 \mathrm{A:B}$ (isocratic); 2-14 min, linear gradient to $85: 15 \mathrm{~A}: \mathrm{B}$; $14-19 \mathrm{~min}$, linear gradient to $82: 18 \mathrm{~A}: \mathrm{B}$; 19-32 min, linear gradient to $65: 35 \mathrm{~A}: \mathbf{B} ; 32-33$ min, linear gradient to $40: 60 \mathrm{~A}: \mathbf{B}$; $33-35 \mathrm{~min}$, linear gradient to $95: 5 \mathrm{~A}: \mathbf{B} ; 35-37 \mathrm{~min}$, 95:5 A:B (isocratic). A flow rate of $3 \mathrm{~mL} / \mathrm{min}$ was used in all experiments.

Method B. For tyrosine radical trap experiments, an Alltech Alltima (Grace) $\mathrm{C}_{18}$ semipreparative column $(5 \mu \mathrm{m}, 100 \AA, 10 \mathrm{~mm} \times 300$ $\mathrm{mm}$ ) was used. Peaks were monitored at 220, 254, 280, and $350 \mathrm{~nm}$ and a mobile phase consisting of acetic acid buffer $\left(0.1 \% \mathrm{v} / \mathrm{v}\right.$ in $\mathrm{H}_{2} \mathrm{O}$, $\mathrm{pH}$ adjusted to $4.0 \pm 0.1$ with $\left.4.0 \mathrm{~N} \mathrm{NH}_{4} \mathrm{OH}\right), \mathbf{A}$, and pure $\mathrm{CH}_{3} \mathrm{OH}, \mathbf{B}$ was used. Gradient conditions: 0-2 min, 70:30 A:B (isocratic); 2-5 min, linear gradient to $60: 40 \mathrm{~A}: \mathrm{B} ; 5-27 \mathrm{~min}$, linear gradient to $55: 45$ A:B; $27-30 \mathrm{~min}$, linear gradient to 70:30 A:B and 30-32 min, 70:30 A:B (isocratic). A flow rate of $3 \mathrm{~mL} / \mathrm{min}$ was used in all experiments. All the solutions for tyrosine derivatives were prepared in $0.1 \mathrm{M}$ phosphate buffer; $\mathrm{pH} 7.40$ and diluted as needed. The tyrosine solution was sonicated for $15 \mathrm{~min}$ to increase its solubility in aqueous solution.

Method C. For phenol radical trap experiments, a Phenomenex Luna $\mathrm{C}_{18}$ analytical column $(5 \mu \mathrm{m}, 100 \AA$, $4.6 \mathrm{~mm} \times 250 \mathrm{~mm})$ was used. Peaks were monitored at 254, 280, 315, and $350 \mathrm{~nm}$ and a mobile phase consisting of acetic acid buffer $\left(0.1 \% \mathrm{v} / \mathrm{v}\right.$ in $\mathrm{H}_{2} \mathrm{O}$, pH adjusted to 4.0 with $\left.4.0 \mathrm{~N} \mathrm{NH}_{4} \mathrm{OH}\right), \mathrm{A}$, and $0.1 \%$ acetic acid (v/v) in pure $\mathrm{CH}_{3} \mathrm{CN}$ (pH not adjusted), B was used. Gradient conditions: 0-2 min, 95:5 A:B (isocratic); 2-14 min, linear gradient to 85:15 A:B; 14-19 min, linear gradient to $82: 18$ A:B; $19-45$ min, linear gradient to $45: 55 \mathrm{~A}: \mathbf{B}$; $45-50 \mathrm{~min}$, linear gradient to $20: 80 \mathrm{~A}: \mathrm{B}$; $50-52 \mathrm{~min}$, linear gradient to 95:5 A:B; 52-53 min, 95:5 A:B (isocratic). A flow rate of $1 \mathrm{~mL} / \mathrm{min}$ was used in all experiments. All the solutions for phenol standards (phenol, catechol, hydroquinone, 2-nitrophenol and 4-nitrophenol) were prepared in $0.1 \mathrm{M}$ phosphate buffer; $\mathrm{pH} 7.40$ and diluted as needed.

Method D. An isocratic method (94:6 A:B; $3 \mathrm{~mL} / \mathrm{min}$ flow rate) was used. The solvents and HPLC column used were the same as in Method A.

Method E. For $\mathrm{NO}_{3}{ }^{-}$detection experiments, an HPLC method reported in the literature was used with minor modifications. ${ }^{26,27} \mathrm{~A}$ Phenomenex Luna $\mathrm{C}_{18}$ analytical column $(5 \mu \mathrm{m}, 100 \AA$, $4.6 \mathrm{~mm} \times 250$ $\mathrm{mm}$ ) was used. Peaks were monitored at 220,280 , and $350 \mathrm{~nm}$, and a mobile phase consisting of $0.01 \mathrm{M} \mathrm{n}$-octylamine ( $\mathrm{pH}$ adjusted to 6.6 with $\left.4.0 \mathrm{M} \mathrm{CH}_{3} \mathrm{COOH}\right)$, A, and pure $\mathrm{CH}_{3} \mathrm{OH}, \mathbf{B}$ was used. An isocratic method (80:20 A:B; $1 \mathrm{~mL} / \mathrm{min}$ flow rate) was used.

For HPLC experiments, the product mixture of the reaction between $\mathrm{NOCbl}$ with $\mathrm{O}_{2}$ was prepared as follows: solid NOCbl was dissolved in anaerobic phosphate buffer $(0.10 \mathrm{M}, \mathrm{pH} 7.40)$ inside the glovebox and removed from the glovebox to expose the sample to air. Tyrosine and phenol were added as needed prior to exposing the sample to air.

HPLC chromatograms of authentic samples of cobalamins $\left(\mathrm{H}_{2} \mathrm{OCbl}^{+}\right.$and $\left.\mathrm{NO}_{2} \mathrm{Cbl}\right)$, phenols (phenol, catechol, hydroquinone, 2-nitrophenol and 4-nitrophenol), tyrosines (tyrosine (Tyr), 3- 
hydroxytyrosine (OH-Tyr) and 3-nitrotyrosine $\left(\mathrm{NO}_{2}\right.$-Tyr $)$ ), and nitrate $\left(\mathrm{NaNO}_{3}\right)$ were independently run to determine the exact retention times for these species. Chromatograms for these standards are given in the Supporting Information. Duplicate HPLC experiments were carried out, giving identical results.

Mass Spectrometry Identification of Unknown HPLC Peak in the Product Mixture of the Reaction of $\mathrm{NOCb}$ with $\mathrm{O}_{2}$. HPLC fractions were collected, combined, and the $\mathrm{pH}$ of the solution $(\sim 40 \mathrm{~mL})$ was adjusted to 7.10. The solution was taken to dryness using rotary evaporator. The $\mathrm{pH}$ of the solution was readjusted to 7.2 (from 6.0) when the volume of the solution was $\sim 4 \mathrm{~mL}$ during the evaporation process (cobalamins are prone to corrin ring destruction and amide hydrolysis under highly acidic conditions ${ }^{28}$ ). ESI-MS (+ve mode) measurements were carried out using an Agilent 6220 Time of Flight (TOF) instrument equipped with a multimode source (MMI) at the Central Instrumentation Facilities in the Department of Chemistry at Colorado State University.

Determination of the Equilibrium Constant for the Reaction of $\mathrm{NOCb} /$ with $\mathrm{O}_{2}$. Varying amounts of an air-saturated buffered solution (0.10 M phosphate buffer; $\mathrm{pH} 7.40)$ were injected using a gastight syringe into an anaerobic solution of NOCbl in phosphate buffer $(0.10$ $\mathrm{M}$, pH 7.40, final conc. $\left.1.00 \times 10^{-4} \mathrm{M}\right)$ in HPLC vials $(\sim 1.8 \mathrm{~mL})$ capped with a septum screw cap. The final volume of the solution was $1.5 \mathrm{~mL}$. The reaction was allowed to proceed to completion for $2 \mathrm{~h}$, and each product solution subsequently diluted to $4.50 \times 10^{-5} \mathrm{M} \mathrm{Cbl}$ with anaerobic phosphate buffer solution $(0.10 \mathrm{M}$ phosphate buffer; $\mathrm{pH} 7.40$ ) inside the glovebox before recording the UV-vis spectrum. Selected spectra were repeated, and the data found to be reproducible to within $\pm 1 \%$ absorbance units.

Probing for Possible Cbl Reaction Intermediates by ${ }^{1} \mathrm{H} N \mathrm{NR}$ Spectroscopy. An aliquot of air-saturated buffer ( 0.50 equiv of $\mathrm{O}_{2}$, $0.10 \mathrm{M}$ phosphate buffer, $\mathrm{pD} 7.40$ ) was injected into an anaerobic NOCbl solution (final conc. $1.00 \times 10^{-3} \mathrm{M}, 0.10 \mathrm{M}$ phosphate buffer, pD 7.40), and the product mixture was transferred to an air-free NMR tube after $15 \mathrm{~min}$ to record the ${ }^{1} \mathrm{H}$ NMR spectrum.

\section{RESULTS}

Kinetic Studies. Upon addition of air-saturated buffer $\left(\mathrm{O}_{2}\right.$ $=1.22 \times 10^{-3} \mathrm{M}$ at $\left.25^{\circ} \mathrm{C}^{24}\right)$ to a solution of NOCbl, UV-vis spectral scans show that $\operatorname{NOCbl}\left(\lambda=318\right.$ and $\left.478 \mathrm{~nm}^{10}\right)$ is cleanly converted to species with spectral features characteristic of nitrocobalamin $\left(\lambda=352,410\right.$, and $\left.526 \mathrm{~nm}^{22}\right)$, Figure $2(\mathrm{pH}$ 7.40, 0.10 M TES buffer, $I=1.0 \mathrm{M} ; \mathrm{NaCF}_{3} \mathrm{SO}_{3}$ ). However the

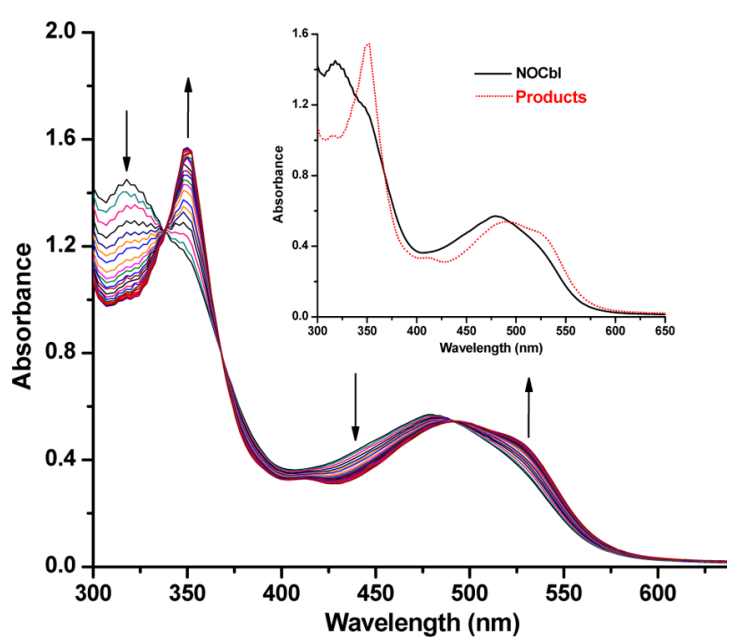

Figure 2. UV-vis spectra for the reaction between NOCbl $(5.00 \times$ $\left.10^{-5} \mathrm{M}\right)$ and excess $\mathrm{O}_{2}\left(6.10 \times 10^{-4} \mathrm{M}\right)$ at $\mathrm{pH} 7.40 \pm 0.02\left(25.0^{\circ} \mathrm{C}\right.$, $0.10 \mathrm{M}$ TES buffer, $\left.I=1.0 \mathrm{M} ; \mathrm{NaCF}_{3} \mathrm{SO}_{3}\right)$. Spectra were recorded every 0.25 s. Inset: Initial spectrum (= NOCbl) and final spectrum (= products).
UV-vis spectra of aquacobalamin/hydroxycobalamin $\left(\mathrm{H}_{2} \mathrm{OCbl}^{+} / \mathrm{HOCbl}, \mathrm{p} K_{\mathrm{a}}\left(\mathrm{H}_{2} \mathrm{OCbl}^{+}\right)=7.8 ;^{22} \lambda_{\max }=351,412\right.$, and $526 \mathrm{~nm}$ at $\mathrm{pH} 7.4)$ and $\mathrm{NO}_{2} \mathrm{Cbl}(\lambda=354,413$, and $531 \mathrm{~nm}$ at $\mathrm{pH}$ 7.4) are practically indistinguishable. ${ }^{22}{ }^{1} \mathrm{H}$ NMR spectroscopy is a useful tool to distinguish between these complexes, since Cbls have 5 characteristic chemical shifts in the aromatic region which are strongly dependent on the $\beta$ axial ligand. ${ }^{22,29}$ The ${ }^{1} \mathrm{H}$ NMR spectrum of a NOCbl solution $\left(1.00 \times 10^{-3} \mathrm{M}, 0.10 \mathrm{M}\right.$ phosphate buffer, $\left.\mathrm{pD} 7.40\right)$ solution exposed to air show that both $\mathrm{NO}_{2} \mathrm{Cbl}$ and $\mathrm{H}_{2} \mathrm{OCbl}^{+} / \mathrm{HOCbl}$ are formed, in a $\sim 37: 63$ ratio ( $\pm 2 \%$; mean value of 3 experiments), Figure 3.

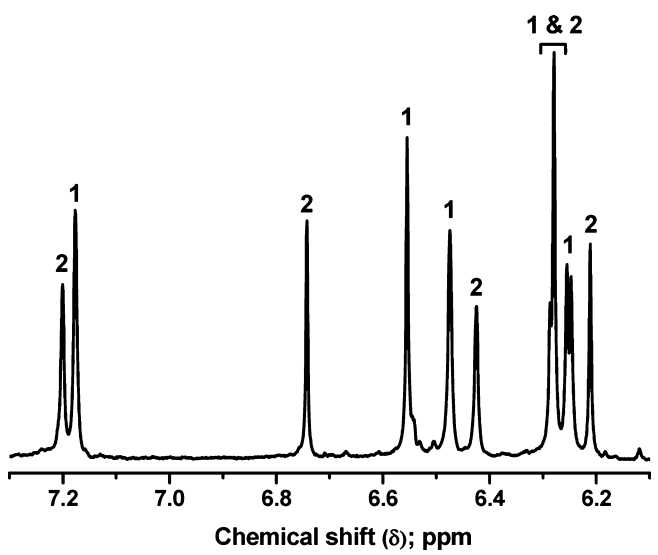

Figure 3. ${ }^{1} \mathrm{H}$ NMR spectrum of a solution of NOCbl $\left(1.00 \times 10^{-3} \mathrm{M}\right)$ exposed to air for $30 \mathrm{~min}$ ( $\mathrm{pD} 7.40,0.10 \mathrm{M}$ phosphate buffer). The peaks at 7.17, 6.55, 6.47, 6.28, and $6.24 \mathrm{ppm}$ correspond to $\mathrm{H}_{2} \mathrm{OCbl}^{+}$/ HOCbl (1) and those at 7.19, 6.74, 6.42, 6.27, and $6.21 \mathrm{ppm}$ correspond to $\mathrm{NO}_{2} \mathrm{Cbl}(2)$. From the integration of the peaks, the ratio of $\left(\mathrm{H}_{2} \mathrm{OCbl}^{+} / \mathrm{HOCbl}\right): \mathrm{NO}_{2} \mathrm{Cbl}$ is $\sim 63: 37$.

The HPLC chromatogram of this same NMR solution and an aqueous solution of NOCbl $\left(1.00 \times 10^{-4} \mathrm{M}, 0.10 \mathrm{M}\right.$ phosphate buffer, $\mathrm{pH}$ 7.40) exposed to air also show formation of $\mathrm{NO}_{2} \mathrm{Cbl} /\left(\mathrm{H}_{2} \mathrm{OCbl}^{+} / \mathrm{HOCbl}\right)$, Figure 4. The fraction of $\mathrm{NO}_{2} \mathrm{Cbl}$ observed by HPLC is smaller than that observed by ${ }^{1} \mathrm{H}$ NMR spectroscopy, because of partial decomposition of $\mathrm{NO}_{2} \mathrm{Cbl}$ on the HPLC column. This was confirmed by injecting an authentic sample of $\mathrm{NO}_{2} \mathrm{Cbl}$, Supporting Information, Figure $\mathrm{S} 1$. Hence both ${ }^{1} \mathrm{H}$ NMR spectroscopy and HPLC clearly show that NOCbl is oxidized by air to form a $\mathrm{NO}_{2} \mathrm{Cbl} /\left(\mathrm{H}_{2} \mathrm{OCbl}^{+} / \mathrm{HOCbl}\right)$ mixture, rather than simple conversion to $\mathrm{NO}_{2} \mathrm{Cbl}$. In Figure 4 an additional small corrinoid peak is observed in the HPLC chromatogram at $350 \mathrm{~nm}$ immediately prior to elution of $\mathrm{H}_{2} \mathrm{OCbl}^{+}$, whose identity will be discussed in detail later.

Kinetic measurements were carried out on the reaction between $\mathrm{NOCbl}$ and $\mathrm{O}_{2}$ under pseudo-first-order conditions. Figure 5 gives a plot of absorbance at $315 \mathrm{~nm}$ versus time for the reaction of NOCbl $\left(7.50 \times 10^{-5} \mathrm{M}\right)$ with $\mathrm{O}_{2}\left(1.00 \times 10^{-5}\right.$ $\mathrm{M})$ at $\mathrm{pH} 7.40\left(25.0{ }^{\circ} \mathrm{C}, 0.10 \mathrm{M}\right.$ TES buffer, $I=1.0 \mathrm{M}$; $\mathrm{NaCF}_{3} \mathrm{SO}_{3}$ ). The data fit well to a single first-order rate equation giving an observed rate constant, $k_{\mathrm{obs}}=(3.89 \pm 0.01)$ $\times 10^{-2} \mathrm{~s}^{-1}$. Data were collected at other NOCbl concentrations, with at least 7.5 times excess NOCbl compared to the concentration of oxygen, to achieve essentially pseudo-firstorder conditions. Keeping $\mathrm{NOCbl}$ rather than $\mathrm{O}_{2}$ in excess improved the reproducibility of the rate constants. A secondorder rate constant $\left(k_{\text {app }}\right)$ was calculated from the plot of $k_{\text {obs }}$ 


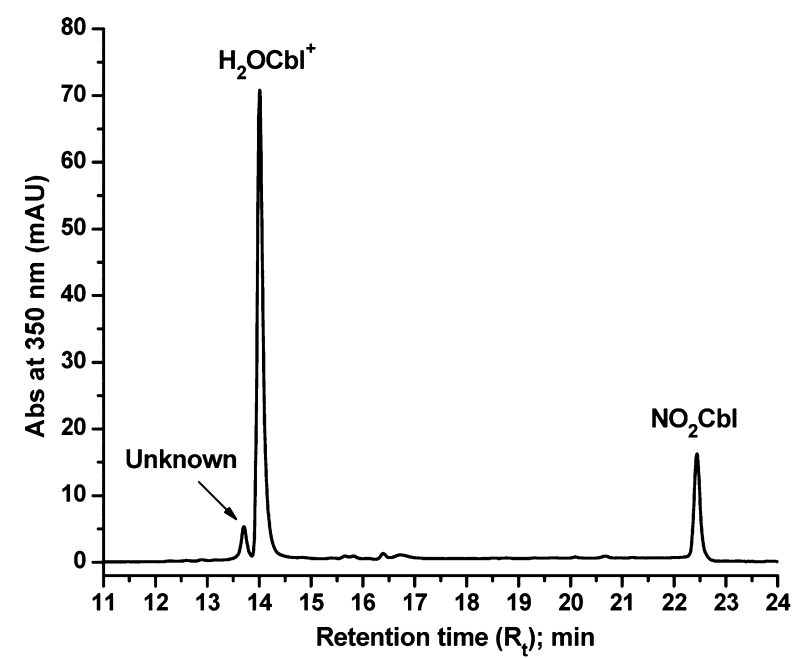

Figure 4. HPLC chromatogram for the products of the reaction between NOCbl $\left(1.00 \times 10^{-4} \mathrm{M}\right)$ and $\mathrm{O}_{2}($ air $)$ at $\mathrm{pH} 7.40(0.10 \mathrm{M}$, phosphate buffer, $\left.25.0{ }^{\circ} \mathrm{C}\right)$. The peaks at 14.0 and $22.4 \mathrm{~min}$ correspond to $\mathrm{H}_{2} \mathrm{OCbl}^{+}(\sim 74 \%)$ and $\mathrm{NO}_{2} \mathrm{Cbl}(\sim 26 \%)$, respectively. $\mathrm{H}_{2} \mathrm{OCbl}^{+}$and $\mathrm{NO}_{2} \mathrm{Cbl}$ amounts are estimated using peak areas and molar extinction coefficients at $350 \mathrm{~nm}$. An unknown corrinoid complex elutes at $13.7 \mathrm{~min}$.

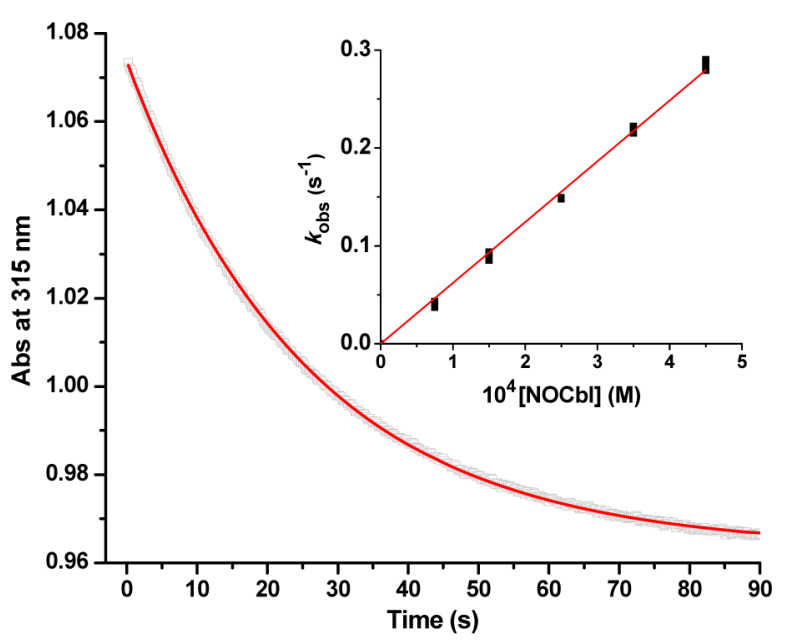

Figure 5. Plot of absorbance at $315 \mathrm{~nm}$ versus time for the reaction of $\mathrm{NOCbl}\left(7.50 \times 10^{-5} \mathrm{M}\right)$ with $\mathrm{O}_{2}\left(1.00 \times 10^{-5} \mathrm{M}\right)$ at $\mathrm{pH} 7.40 \pm 0.02$ $\left(25.0{ }^{\circ} \mathrm{C}, 0.10 \mathrm{M}\right.$ TES buffer, $\left.I=1.0 \mathrm{M} ; \mathrm{NaCF}_{3} \mathrm{SO}_{3}\right)$. The first order fit of the data gives the observed rate constant $\left(k_{\mathrm{obs}}\right)=(3.89 \pm 0.01) \times$ $10^{-2} \mathrm{~s}^{-1}$. Inset: Plot of $k_{\mathrm{obs}}$ versus [NOCbl] for the same reaction giving a second-order rate constant $\left(k_{\text {app }}\right)=621 \pm 6 \mathrm{M}^{-1} \mathrm{~s}^{-1}$.

versus NOCbl concentration (inset to Figure 5). A straight line passing through the origin is consistent with the ratedetermining step involving the reaction of $\mathrm{O}_{2}$ with $\mathrm{NOCbl}$, giving an apparent second-order rate constant, $k_{\text {app }}=621 \pm 6$ $\mathrm{M}^{-1} \mathrm{~s}^{-1}$ at $\mathrm{pH} 7.40$.

Similar experiments were carried out at other $\mathrm{pH}$ conditions and $k_{\text {app }}$ values determined from plots of $k_{\text {obs }}$ versus [NOCbl] at each $\mathrm{pH}$ condition, Supporting Information, Figures S2-S8. Figure 6 summarizes the results. The reaction rate increases with increasing $\mathrm{pH}$ to become $\mathrm{pH}$ independent for $\mathrm{pH}>7$. Importantly, in acidic aqueous solution $\mathrm{NOCbl}$ exists in a mixture of its "base-on" (the $\mathrm{N}$-bound 5,6-dimethylbenzimidazole (DMB) is coordinated at the $\alpha$-axial site of the $\mathrm{Cbl}$ ) and "base-off" form (a water displaces the 5,6-dimethylbenzimida-

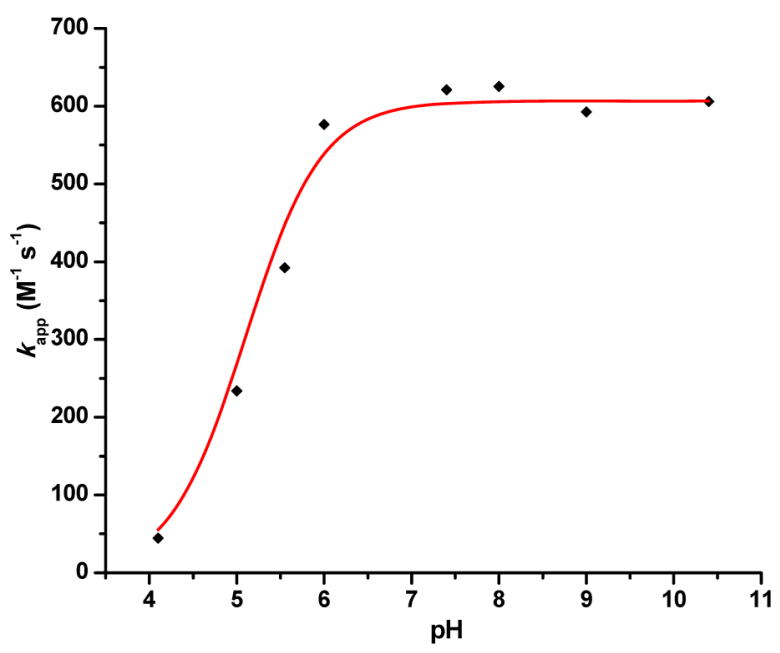

Figure 6. Plot of second-order rate constant $\left(k_{\text {app }}\right)$ versus $\mathrm{pH}$ for the reaction between $\mathrm{NOCbl}$ and $\mathrm{O}_{2}$. The data have been fitted to eq 1 in the text fixing $\mathrm{p} K_{\text {base-off }}(\mathrm{NOCbl})=5.1$ and $K_{\mathrm{Co}}=1.9$, giving the rate constant $\left(k_{\mathrm{NOCbl}}\right)=926 \pm 20 \mathrm{M}^{-1} \mathrm{~s}^{-1}$.

zole from the $\alpha$-axial site), Scheme 1. The data in Figure 6 were fitted to eq 1 assuming that only base-on NOCbl, not the two

Scheme 1. Base-on and Base-off Forms of NOCbl Formed in Aqueous Solution

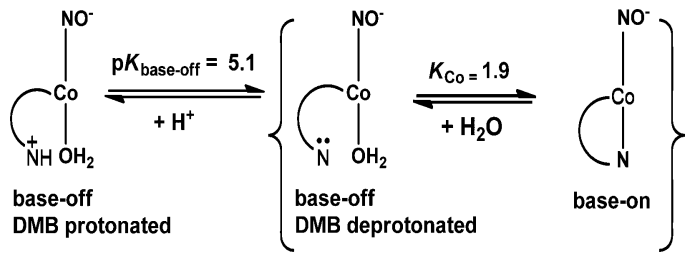

base-off complexes, reacts with $\mathrm{O}_{2}$, with the value of $\mathrm{p} K_{\text {base-off }}(\mathrm{NOCbl})$ fixed to $5.1^{10}$ and $K_{\mathrm{Co}}$ fixed to $1.9 .^{4}$ The best fit of the data in Figure 6 to eq 1 gives the rate constant, $k_{\mathrm{NOCbl}}=926 \pm 20 \mathrm{M}^{-1} \mathrm{~s}^{-1}$. The role of the ligand trans to the $\mathrm{NO}^{-}$with respect to the reactivity of nitroxyl cobalt complexes with $\mathrm{O}_{2}$ is well established, with strong $\sigma$ donating ligands significantly increasing the rate of the reaction. ${ }^{23,30}$

$$
k_{\mathrm{NOCbl}}=\frac{k_{\text {app }} K_{\text {base-off }} K_{\mathrm{Co}}}{\left(10^{-\mathrm{pH}}+K_{\text {base-off }}\right)\left(K_{\mathrm{Co}}+1\right)}
$$

To determine the thermodynamic parameters $\Delta H^{\ddagger}$ and $\Delta S^{\ddagger}$, temperature dependence studies were carried out for the reaction of $\mathrm{NOCbl}$ with $\mathrm{O}_{2}$ in the $15.0-45.0{ }^{\circ} \mathrm{C}$ range at $\mathrm{pH}$ $7.40 \pm 0.02$. Under these conditions NOCbl exists in its baseon form. Figure 7 gives the Eyring plot of $\ln (k / T)$ versus $1 / T$. The slope and intercept of the plot give $\Delta H^{\ddagger}=29 \pm 1.4 \mathrm{~kJ}$ $\mathrm{mol}^{-1}$ and $\Delta S^{\ddagger}=-94.0 \pm 4.2 \mathrm{~J} \mathrm{~K}^{-1} \mathrm{~mol}^{-1}$, respectively.

Determination of the Equilibrium Constant $\left(K_{\mathrm{eq}}\right)$. Equilibrated solutions of NOCbl $\left(1.00 \times 10^{-4} \mathrm{M}\right)$ with varying numbers of equivalents of $\mathrm{O}_{2}(0-12.2$ equiv) were prepared, and the product solutions diluted to $4.50 \times 10^{-5} \mathrm{M}$ before recording UV-vis spectra, Figure 8 . Note that scatter in the absorbance spectra is observed, since individual solutions were prepared for each $\mathrm{O}_{2}$ concentration and transferred one by one to a cuvette to record the UV-vis spectrum. From a plot of absorbance at $352 \mathrm{~nm}$ versus concentration of $\mathrm{O}_{2}$ (inset to Figure 8), it is clear that the reaction requires excess $\mathrm{O}_{2}$ to 


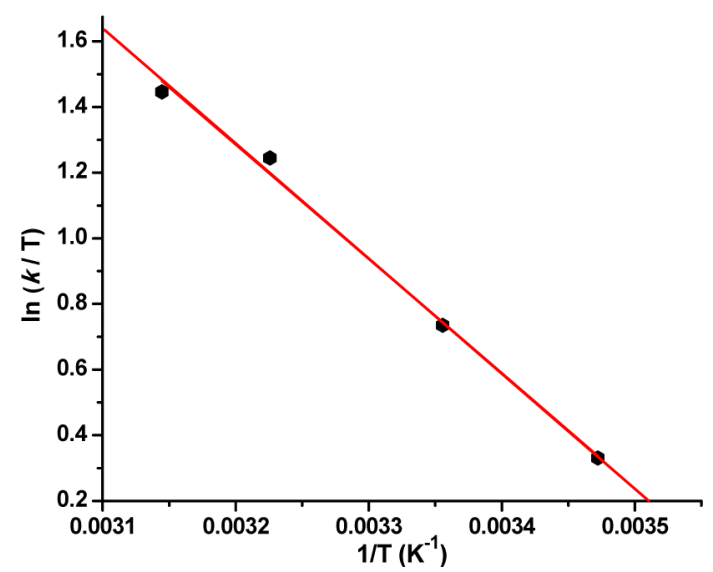

Figure 7. Plot of $\ln (k / T)$ versus $1 / T$ (Eyring plot) for the reaction of NOCbl with $\mathrm{O}_{2}$ at pH $7.40 \pm 0.02(0.10 \mathrm{M}$ TES buffer, $I=1.0 \mathrm{M}$; $\left.\mathrm{NaCF}_{3} \mathrm{SO}_{3}\right)$. The slope and the intercept of the Eyring plot give $\Delta H^{\ddagger}$ $=29 \pm 1.4 \mathrm{~kJ} \mathrm{~mol}^{-1}$ and $\Delta S^{\ddagger}=-94.0 \pm 4.2 \mathrm{~J} \mathrm{~K}^{-1} \mathrm{~mol}^{-1}$, respectively.

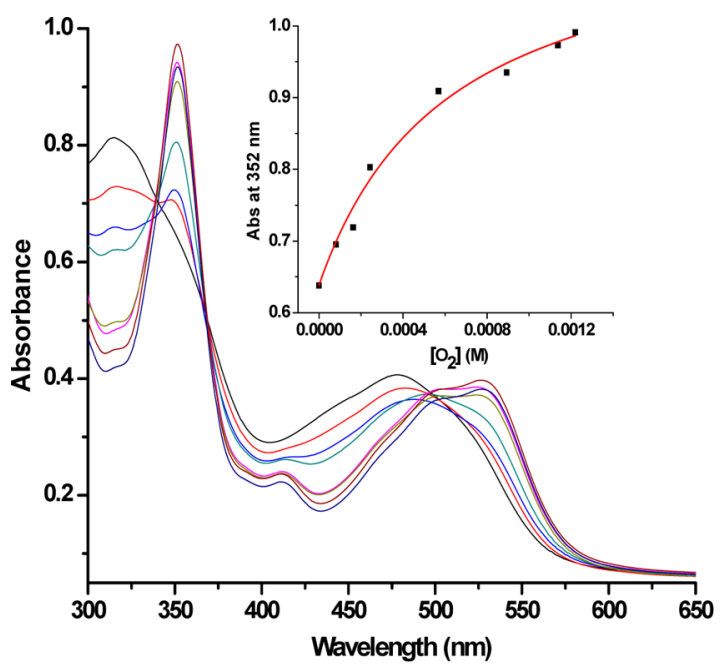

Figure 8. UV-vis spectra for equilibrated solutions of NOCbl $(1.00 \times$ $\left.10^{-4} \mathrm{M}\right)$ with varying numbers of equivalents of $\mathrm{O}_{2}(0-12.2$ equiv) at $\mathrm{pH} 7.40$ (0.10 M phosphate buffer) at $25.0{ }^{\circ} \mathrm{C}$. Inset: Plot of absorbance at $352 \mathrm{~nm}$ versus $\left[\mathrm{O}_{2}\right]$. The best fit of the data to eq 2 in the text gave an equilibrium constant, $K_{\text {eq }}=(1.62 \pm 0.34) \times 10^{3} \mathrm{M}^{-1}$.

proceed to completion. The data were fitted to eq 2. $A_{0}$ and $A_{\infty}$ represent the absorbance in the absence of $\mathrm{O}_{2}$ and the absorbance after the complete formation of products, respectively, and $A_{\text {obs }}$ is the observed absorbance at a specific $\mathrm{O}_{2}$ concentration. The best fit of the data to eq 2 gave an equilibrium constant $\left(K_{\mathrm{eq}}\right)$ of $(1.62 \pm 0.34) \times 10^{3} \mathrm{M}^{-1}(\mathrm{pH}$ 7.40).

$$
A_{\mathrm{obs}}=\left(A_{0}+A_{\infty} K_{\mathrm{eq}}\left[\mathrm{O}_{2}\right]\right) /\left(1+K_{\mathrm{eq}}\left[\mathrm{O}_{2}\right]\right)
$$

Probing for Reaction Intermediates. $0.50 \mathrm{~mol}$ equiv of $\mathrm{O}_{2}$ was added to an anaerobic solution of NOCbl $\left(1.00 \times 10^{-3}\right.$ $\mathrm{M})$, and the ${ }^{1} \mathrm{H}$ NMR spectrum of the product mixture recorded ( $\mathrm{pD}$ 7.40). Three sets of $\mathrm{Cbl}$ peaks were observed in the product mixture corresponding to unreacted $\mathrm{NOCbl}$ and the $\mathrm{NO}_{2} \mathrm{Cbl}$ and $\mathrm{H}_{2} \mathrm{OCbl}^{+} / \mathrm{HOCbl}$ products, Supporting Information, Figure S9. Hence significant amounts of other $\mathrm{Cbl}$ complexes are not observed by ${ }^{1} \mathrm{H}$ NMR spectroscopy with the addition of less than $1 \mathrm{~mol}$ equiv of $\mathrm{O}_{2}$.
It has been proposed that a transition metal-bound peroxynitrite intermediate is formed upon reacting nitrosyl transition metal complexes with $\mathrm{O}_{2}$ (see below). ${ }^{23,30-35}$ This complex may decompose to generate $\mathrm{NO}_{3}{ }^{-},{ }^{\bullet} \mathrm{OH}$, and ${ }^{\bullet} \mathrm{NO}_{2}$ intermediates. ${ }^{31,32,36,37}$ HPLC experiments showed that $\mathrm{NO}_{3}{ }^{-}$ is present in the product mixture, Supporting Information, Figure $\mathrm{S} 10$, in an amount consistent with the $\left(\mathrm{H}_{2} \mathrm{OCbl}^{+} /\right.$ $\mathrm{HOCbl}): \mathrm{NO}_{2} \mathrm{Cbl}$ product ratio of $\sim 63: 37$. Experiments were also carried out to probe for formation of other noncobalamin corrinoid products, which may arise as a result of ${ }^{\bullet} \mathrm{OH}$ and/or ${ }^{-} \mathrm{NO}_{2}$ intermediates attacking the corrin ring of the $\mathrm{Cbl}$ complex. The product mixture of the reaction between $\mathrm{NOCbl}$ $\left(1.00 \times 10^{-3} \mathrm{M}\right)$ and $\mathrm{O}_{2}$ was treated with excess solid $\mathrm{KCN}$ $(\mathrm{pH}>10)$ to convert all corrinoid complexes to their dicyano forms. The $\mathrm{pH}$ was subsequently lowered to 3 before bubbling the solution with air to convert dicyanocobalamin $\left((\mathrm{CN})_{2} \mathrm{Cbl}^{-}\right)$to $\mathrm{CNCbl}$ and to remove excess cyanide (as $\mathrm{HCN}) .{ }^{25}$ Figure S11 in the Supporting Information shows a major peak $(\sim 96 \%$ at $280 \mathrm{~nm})$ in the HPLC chromatogram of the product mixture, with a retention time and UV-vis spectrum identical to CNCbl. This suggests that almost all of the corrinoid products are cobalamin complexes. HPLC fractions for this peak were collected and taken to dryness. ESI-MS confirmed that this peak does indeed correspond to $\mathrm{CNCbl}$; that is, corrin ring modifications are not present to any significant extent in the major cobalamin products $\left(\left(\mathrm{H}_{2} \mathrm{OCbl}^{+}\right)\right.$ $\left.\mathrm{HOCbl})+\mathrm{NO}_{2} \mathrm{Cbl}\right)$, Supporting Information, Figure S12.

To further investigate whether the free radicals ${ }^{\circ} \mathrm{OH}$ and $-\mathrm{NO}_{2}$ are formed in solution upon reacting $\mathrm{NOCbl}$ with $\mathrm{O}_{2}$, the products of the reaction between $\mathrm{NOCbl}$ and $\mathrm{O}_{2}$ were determined in the presence of the established ${ }^{\circ} \mathrm{OH} /{ }^{\bullet} \mathrm{NO}_{2}$ trapping agent phenol. Phenol traps the ${ }^{\circ} \mathrm{OH}$ and ${ }^{\circ} \mathrm{NO}_{2}$ intermediates formed upon the spontaneous decomposition of $\mathrm{ONOOH}$ in aqueous solution $(\mathrm{pH} 6.8)$ to form hydroquinone $(3 \%)$, catechol $(0.2 \%)$, 2-nitrophenol $(3 \%)$, and 4 nitrophenol (2.2\%). ${ }^{38,39}$ An HPLC method was developed suitable for separating the hydroxylated and nitrated phenol derivatives from phenol, Supporting Information, Figure S13. A control experiment showed that formation of $1 \%$ (relative to the $\mathrm{Cbl}$ concentration) hydroquinone, catechol, 4-nitrophenol, and 2-nitrophenol would be detectable in the HPLC chromatogram of the product mixture, Supporting Information, Figure S14. Both 4-nitrophenol (33.3 $\mathrm{min},<1 \%$; no attempt was made to quantitate the amounts of the phenol products) and 2nitrophenol $(38.7 \mathrm{~min},<1 \%)$ were clearly observed in the HPLC chromatogram of the products of the reaction of NOCbl with air in the presence of excess phenol $(0.10 \mathrm{M})$, Figure 9, indicating that free ${ }^{\circ} \mathrm{NO}_{2}$ radicals are formed during the reaction. However, hydroxylated phenol derivatives (hydroquinone and catechol) proved more difficult to observe in the presence of the $\mathrm{Cbl}$ products. The peak for catechol $(17.3 \mathrm{~min}$ ) overlaps with cobalamin impurities, and hydroquinone was also not detected.

To probe further for formation of a ${ }^{\bullet} \mathrm{OH}$ intermediate, a second ${ }^{\bullet} \mathrm{OH} /{ }^{\bullet} \mathrm{NO}_{2}$ trapping agent, tyrosine (Tyr), was used. Tyr traps the ${ }^{\bullet} \mathrm{OH}$ and ${ }^{\circ} \mathrm{NO}_{2}$ intermediates formed during ONOOH decomposition ( $\mathrm{pH} 7.40$ ) to give a much larger yield of the hydroxylated trapped product 3-hydroxytyrosine $(\mathrm{OH}-$ Tyr, 9\%) in addition to 3-nitrotyrosine $\left(\mathrm{NO}_{2}-\mathrm{Tyr}, 5 \%\right){ }^{40-45}$ Control experiments showed that both OH-Tyr (3\%) and $\left(\mathrm{NO}_{2}\right.$-Tyr) (3\%) are detected in the presence of the $\mathrm{Cbl}$ reaction products, Supporting Information, Figure S15. When NOCbl $\left(1.00 \times 10^{-3} \mathrm{M}\right)$ was reacted with air in the presence of 

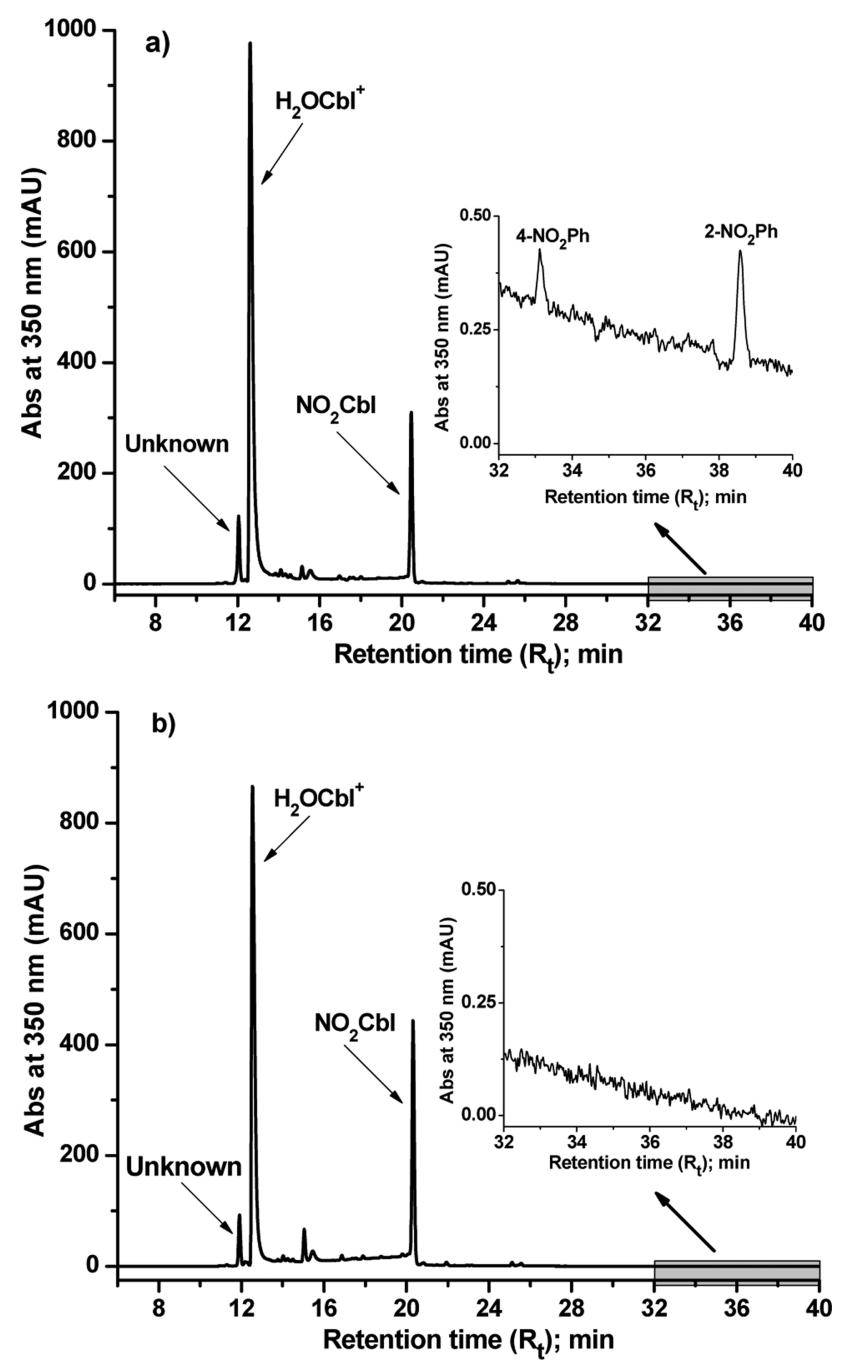

Figure 9. HPLC chromatogram for the products of the reaction between NOCbl $\left(1.00 \times 10^{-3} \mathrm{M}\right)$ and $\mathrm{O}_{2}$ (air) in the (a) presence and (b) absence of excess phenol $(0.10 \mathrm{M})$. The prominent peaks at 12.0, 12.6, and 20.5 correspond to a novel corrinoid complex, $\mathrm{H}_{2} \mathrm{OCbl}^{+}$and $\mathrm{NO}_{2} \mathrm{Cbl}$, respectively. Note that the peak for phenol $(26.6 \mathrm{~min}$; Supporting Information, Figure S10e) is not observed in Figure 9a since phenol does not absorb at $350 \mathrm{~nm}$. The insets to panels $\mathrm{a}$ and $\mathrm{b}$ are enlarged representations of the 32-40 min region, showing the presence of 4-nitrophenol (4- $\left.\mathrm{NO}_{2} \mathrm{Ph} ; 33.3 \mathrm{~min}\right)$ and 2-nitrophenol (2$\mathrm{NO}_{2} \mathrm{Ph} ; 38.7 \mathrm{~min}$ ) in (a) only. Two further minor corrinoid peaks are observed at 15.0 and $15.5 \mathrm{~min}$, which decrease in relative intensity in the presence of phenol. No attempts were made to characterize these complexes.

excess Tyr $\left(6.00 \times 10^{-3} \mathrm{M}\right)$, a small amount $(14.8 \mathrm{~min},<1 \%)$ of $\mathrm{OH}-\mathrm{Tyr}$ was clearly observed in the HPLC chromatogram, Figure 10. Using this HPLC method $\mathrm{NO}_{2}$-Tyr was not observed, most likely because of overlap with $\mathrm{Cbl}$ impurities.

An additional small corrinoid peak eluting immediately prior to elution of $\mathrm{H}_{2} \mathrm{OCbl}^{+}$was observed at $350 \mathrm{~nm}$ in the HPLC chromatogram of the product mixture of the reaction between $\mathrm{NOCbl}$ and $\mathrm{O}_{2}$, Figures 4 and 9, with a UV-vis spectrum indistinguishable from $\mathrm{H}_{2} \mathrm{OCbl}^{+}$. HPLC fractions of the unknown complex were collected using an isocratic HPLC method to achieve complete separation from $\mathrm{H}_{2} \mathrm{OCbl}^{+}$, pooled together, and analyzed by mass spectrometry (see Experimental Section and Figures $S 13 \mathrm{f}$ and $\mathrm{S} 16$ in the Supporting Information for details). The complex has $\mathrm{m} / z$ peaks assignable
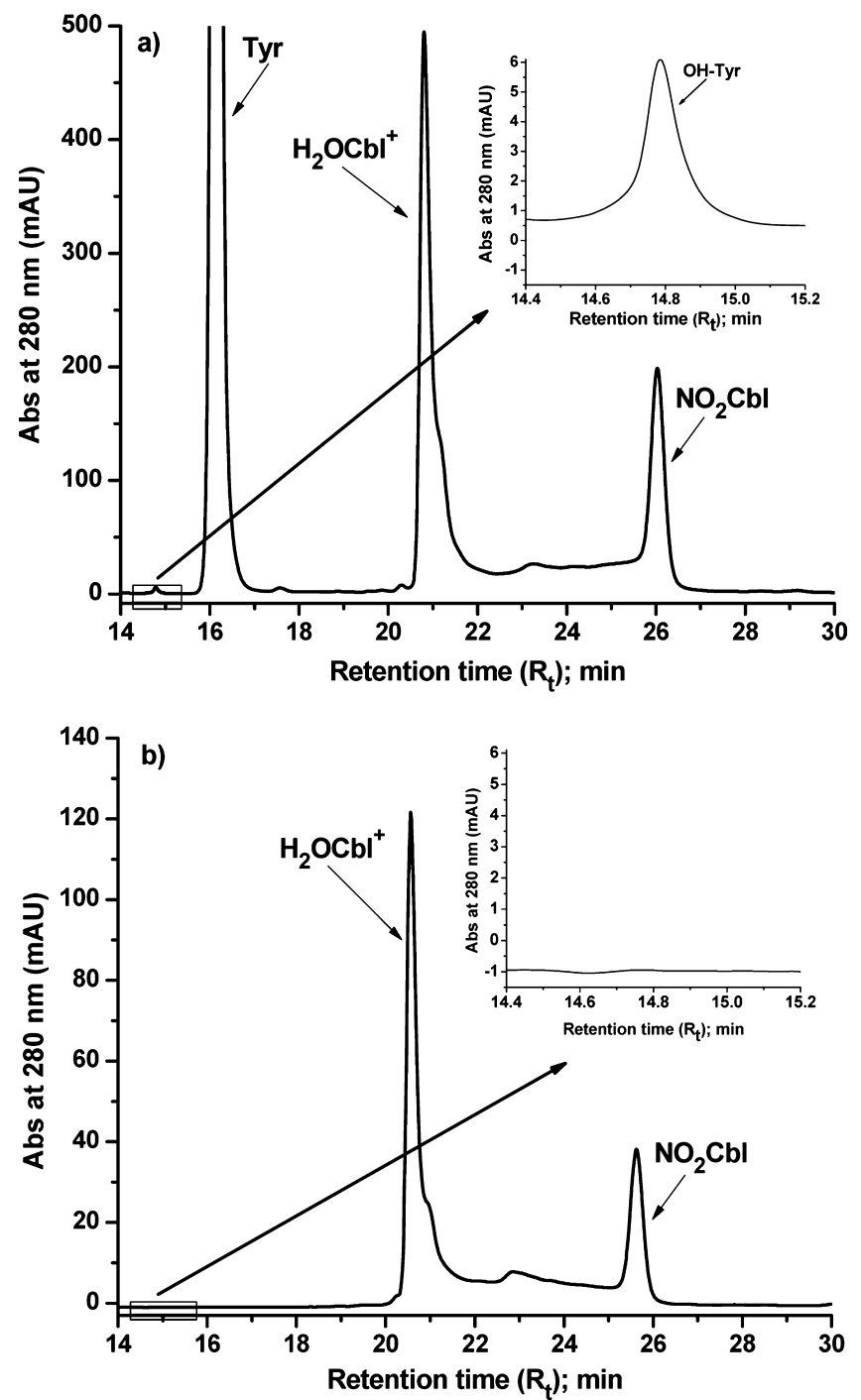

Figure 10. HPLC chromatogram for the products of the reaction of NOCbl $\left(1.00 \times 10^{-3} \mathrm{M}\right)$ with air in the $(\mathrm{a})$ presence and $(\mathrm{b})$ absence of excess Tyr $\left(6.00 \times 10^{-3} \mathrm{M}\right)$. The peaks at $14.8,16.1,20.8$, and 26.0 min correspond to $\mathrm{OH}-\mathrm{Tyr}, \mathrm{Tyr}, \mathrm{H}_{2} \mathrm{OCbl}^{+}$, and $\mathrm{NO}_{2} \mathrm{Cbl}$, respectively. The insets to panels $\mathrm{a}$ and $\mathrm{b}$ are enlarged representations of the region where $\mathrm{OH}-\mathrm{Tyr}$ elutes from the column.

to a $\mathrm{Cbl}$ complex minus two hydrogen atoms, $\mathrm{Cbl}-2 \mathrm{H}$ (observed $\mathrm{m} / z=1327.53$, calculated $\mathrm{m} / z$ for $[(\mathrm{Cbl}-2 \mathrm{H})+$ $\left.\mathrm{H}]^{+}, \mathrm{C}_{62} \mathrm{H}_{87} \mathrm{CoN}_{13} \mathrm{O}_{14} \mathrm{P}=1327.56\right)$ and observed $\mathrm{m} / z=664.27$ (calculated $m / z$ for $[(\mathrm{Cbl}-2 \mathrm{H})+2 \mathrm{H}]^{2+}, \mathrm{C}_{62} \mathrm{H}_{88} \mathrm{CoN}_{13} \mathrm{O}_{14} \mathrm{P}=$ 664.28)). Although corrinoid ring modifications have been proposed to occur in numerous studies, ${ }^{28,46,47}$ typically these complexes are not fully characterized. One possibility is that abstraction of a $\mathrm{H}$ atom by a ${ }^{\bullet} \mathrm{OH}$ radical at the $\mathrm{C} 8$ position (Figure 1) of the corrin occurs. (Unpublished data from our lab shows that ${ }^{\circ} \mathrm{NO}_{2}$ does not react with the corrin ring.) This results in intramolecular transfer of an unpaired electron to the Co center, and subsequent attack of a deprotonated $\mathrm{N}$-amide group of side-chain $c$ at the $\mathrm{C} 8$ carbocation results in formation of the well-known $\mathrm{Co}$ (II) $c$-lactam derivative of aquacobalamin. ${ }^{28}$ This complex is oxidized to the corresponding $\mathrm{Co}$ (III) complex in the presence of air (a "dehydrovitamin $\mathrm{B}_{12}$ " derivative). ${ }^{48} c$-Lactam derivatives of $B_{12}$ have very similar UVvis spectra and chromatographic behavior to the parent $B_{12}$ complexes. $^{47}$ Furthermore the $c$-lactam of $\mathrm{CNCbl}$ elutes 
immediately prior to $\mathrm{CNCbl}$ on a $\mathrm{C} 18$ reverse phase HPLC column, consistent with the retention time of our unknown corrinoid species. ${ }^{49}$ However an X-ray structure of the corrinoid product is clearly required to unequivocally characterize this complex, which is beyond the scope of this study.

To summarize, HPLC evidence for formation of ${ }^{\bullet} \mathrm{OH}$ and ${ }^{-} \mathrm{NO}_{2}$ radical intermediates was obtained using tyrosine and phenol, respectively, as trapping agents. Observation of a small amount of a (non-Cbl) corrinoid species by HPLC with a retention time close to that of $\mathrm{H}_{2} \mathrm{OCbl}^{+}$is also consistent with formation of a ${ }^{\bullet} \mathrm{OH}$ intermediate. The amounts of the hydroxylated and nitrated products in the phenol and Tyr trapping experiments were considerably smaller than that observed for $\mathrm{ONOO}(\mathrm{H})$ decomposition in the presence of the identical trapping agents. The possibility that ${ }^{\circ} \mathrm{OH}$ and/or ${ }^{-} \mathrm{NO}_{2}$ were instead trapped by the buffer was disproved since the yields of the trapped products were unchanged in the absence of phosphate buffer. Finally, the presence of $\mathrm{NO}_{3}{ }^{-}$in the product mixture was also demonstrated using HPLC.

\section{DISCUSSION}

Others have proposed formation of a peroxynitrito intermediate upon the oxidation of nitrosyl/nitroxyl metal complexes by oxygen, ${ }^{23,30-35}$ eq 3 , or the reaction of $\mathrm{NO}$ with superoxometal complexes, eq $4 .^{37,38,50-52}$

$$
\begin{aligned}
& \mathrm{M}^{(n-1)+}-\mathrm{NO} / \mathrm{M}^{n+}-\mathrm{NO}^{-}+\mathrm{O}_{2} \\
& \rightarrow \mathrm{M}^{n+}-\mathrm{N}(\mathrm{O}) \mathrm{OO}^{-}\left(\text {or } \mathrm{M}^{n+}-\mathrm{OONO}^{-}\right) \\
& \rightarrow \text { products.... } \\
& \mathrm{M}^{(n-1)+}-\mathrm{O}_{2} / \mathrm{M}^{n+}-\mathrm{O}_{2}^{-}+\mathrm{NO} \\
& \quad \rightarrow \mathrm{M}^{n+}-\mathrm{OONO}^{-} \\
& \rightarrow \text { products... }
\end{aligned}
$$

Thus far two peroxynitrito complexes have been isolated. Koppenol et al. synthesized $\left[\mathrm{Co}(\mathrm{CN})_{5} \mathrm{OONO}\right]^{3-}$ by reacting $\left[\mathrm{Co}(\mathrm{CN})_{5} \mathrm{O}_{2}\right]^{3-}$ with 1 equiv of $\mathrm{NO}_{(\mathrm{g})}{ }^{38}$ This complex was remarkably stable in aqueous solution, eventually hydrolyzing. Recently a $\mathrm{Cu}(\mathrm{I})$ peroxynitrito complex was synthesized by reacting $\mathrm{Cu}(\mathrm{II})-\mathrm{NO}$ with $\mathrm{H}_{2} \mathrm{O}_{2} \cdot{ }^{53}$ X-ray structures were not reported for either complex.

While peroxynitrite $\left(\mathrm{ONOO}^{-}\right)$is relatively stable in solution, ${ }^{50} \mathrm{ONOOH}$ rapidly undergoes $\mathrm{O}-\mathrm{O}$ bond homolysis to produce caged ${ }^{\circ} \mathrm{ONO}$ and ${ }^{\bullet} \mathrm{OH}$, which recombine to form $\mathrm{NO}_{3}^{-}+\mathrm{H}^{+}$, Scheme $2 .^{54-56}$ It has also been proposed that direct intramolecular rearrangement of $\mathrm{ONOOH}$ occurs, to also yield $\mathrm{NO}_{3}{ }^{-}+\mathrm{H}^{+} .56$ Controversy currently exists concerning the extent of intramolecular rearrangement versus $\mathrm{O}-\mathrm{O}$ bond homolysis. ${ }^{54-56} \mathrm{ONOO}^{-}$decomposes much more slowly via similar reaction pathways, Scheme 2 .

Given that $\mathrm{p} K_{\mathrm{a}}(\mathrm{ONOOH})$ is $6.8^{57}$ and that the $\mathrm{p} K_{\mathrm{a}}$ of a ligand lowers upon coordination of the ligand to a metal center, ${ }^{58}$ it is likely that the intermediate is $\mathrm{Co}(\mathrm{III})-\mathrm{N}(\mathrm{O}) \mathrm{OO}^{-}$ rather than $\mathrm{Co}(\mathrm{III})-\mathrm{N}(\mathrm{O}) \mathrm{OOH}$ in the $\mathrm{pH}$ range of our study. From kinetic studies on the reaction of $\mathrm{NOCbl}$ with $\mathrm{O}_{2}$ it was found that the rate-determining step is first-order in both $[\mathrm{NOCbl}]$ and $\left[\mathrm{O}_{2}\right]$, and that only base-on NOCbl, not base-off $\mathrm{NOCbl}$, reacts with $\mathrm{O}_{2}\left(k_{\mathrm{NOCbl}}=926 \pm 20 \mathrm{M}^{-1} \mathrm{~s}^{-1}, 25.0^{\circ} \mathrm{C}\right.$, $\mathrm{pH} 7.40,0.10 \mathrm{M}$ phosphate buffer, $I=1.0 \mathrm{M} ; \mathrm{NaCF}_{3} \mathrm{SO}_{3}$ ). Others have also observed that the presence of strong base coordinated trans to the nitrosyl group of cobalt nitrosyl
Scheme 2. Decomposition Pathways for $\mathrm{ONOOH}$ and $\mathrm{ONOO}^{-a}$
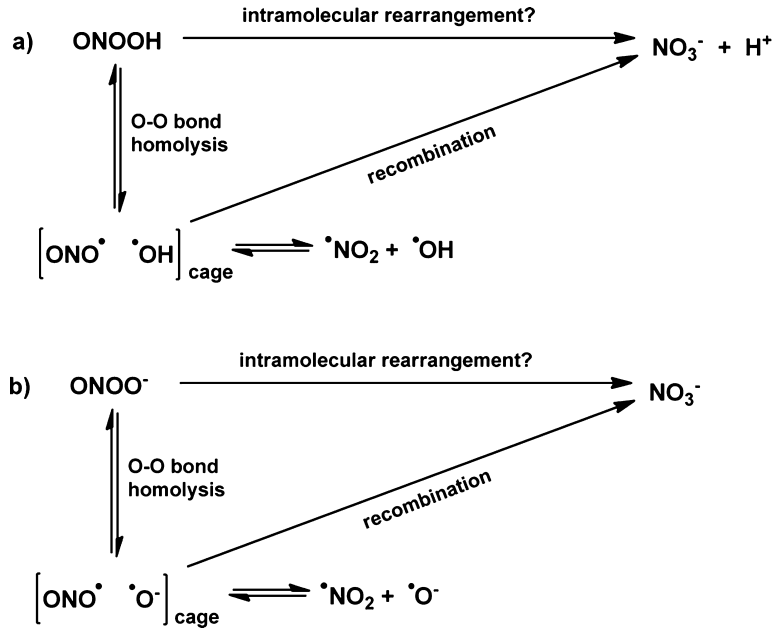

${ }^{a} \mathrm{ONOOH}$ also reacts with $\mathrm{ONOO}^{-}$to produce $2 \mathrm{NO}_{2}{ }^{-}+\mathrm{O}_{2}{ }^{56}$

complexes leads to an accelerated rate of reaction with $\mathrm{O}_{2}{ }^{23,30,59}$ and the same is also true for other metal-NO complexes. ${ }^{60}$ Reaction intermediates were not observed for the $\mathrm{NOCbl}+\mathrm{O}_{2}$ reaction even with 0.5 equiv of $\mathrm{O}_{2}$, consistent with rate-determining electrophilic attack of $\mathrm{O}_{2}$ on $\mathrm{NOCbl}$, with subsequent rapid reactions to generate the $\mathrm{H}_{2} \mathrm{OCbl}^{+} /$ $\mathrm{HOCbl}$ and $\mathrm{NO}_{2} \mathrm{Cbl}$ products. An overall equilibrium constant of $(1.62 \pm 0.34) \times 10^{3} \mathrm{M}^{-1}$ was determined at $\mathrm{pH} 7.40$ (25.0 $\left.{ }^{\circ} \mathrm{C}\right)$. Interestingly, others have reported that the reaction between $\mathrm{Co}-\mathrm{NO}$ and ${ }^{1} /{ }_{2} \mathrm{O}_{2}$ was stoichiometric, ${ }^{30}$ and several additional experiments were carried out by us to confirm that this is not the case for the $\mathrm{NOCbl}+\mathrm{O}_{2}$ reaction. On retrospect this result is expected, given that in solution the base-off, 5,6dimethylbenzimidazole (DMB) deprotonated form of NOCbl exists in equilibrium with base-on NOCbl, Scheme $1,{ }^{4}$ and since $\mathrm{H}_{2} \mathrm{O}$ is a weak trans $\sigma$ donor ligand, the base-off complex is unlikely to react with $\mathrm{O}_{2}$.

Others have proposed for their systems that the nitrosyl ligand initially dissociates from the metal center followed by formation of the superoxometal complex which subsequently reacts with $\mathrm{NO}$ to form an $O$-bound peroxynitritometal complex. $^{31,32,34,35}$ It has also been suggested that oxygen is first reduced by the metal center of a Re-NO complex to superoxide, which then reacts with the metal complex to form an $\mathrm{N}$-bound peroxynitritorhenium intermediate. ${ }^{33}$ However these reaction pathways seem unlikely for the $\mathrm{NOCbl} / \mathrm{O}_{2}$ system since the rate-determining step is first-order in both the $\mathrm{NOCbl}$ and $\mathrm{O}_{2}$ concentrations. Furthermore a large negative value of $\Delta S^{\ddagger}$ supports an associative rate-determining step for the reaction between $\mathrm{NOCbl}$ and $\mathrm{O}_{2}$, consistent with electrophilic attack of $\mathrm{O}_{2}$ on the $\mathrm{N}$ of NOCbl to form a $\mathrm{N}$ bound peroxynitrito complex. A bimolecular mechanism for formation of the corresponding nitro-Co(III) complex from the peroxynitritocobalt(III) intermediate has been proposed by others, with $\mathrm{Co}(\mathrm{III})$-bound peroxynitrite reacting with $\mathrm{Co}(\mathrm{III})$ $\mathrm{NO}^{-}$to give $\mathrm{NO}_{2} \mathrm{Cbl}$, Scheme 3. ${ }^{30,31}$ If the reaction proceeds via this type of reaction pathway, the $\mathrm{NO}_{2} \mathrm{Cbl}:\left(\mathrm{H}_{2} \mathrm{OCbl}^{+}+\right.$ $\mathrm{HOCbl}$ ) product ratio will be dependent on the total cobalamin concentration, ${ }^{31}$ with more $\mathrm{NO}_{2} \mathrm{Cbl}$ expected at higher cobalamin concentrations. However, HPLC experiments showed that the $\mathrm{NO}_{2} \mathrm{Cbl}: \mathrm{H}_{2} \mathrm{OCbl}^{+}$product ratio is the same 
Scheme 3. Proposed Mechanism for Formation of Nitrocobalamin $\left(\mathrm{NO}_{2} \mathrm{Cbl}\right)$ Product from the Peroxynitritocobalt(III) Intermediate

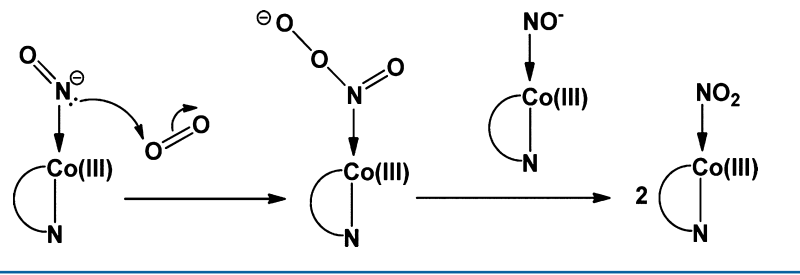

within experimental error for products of the reaction between $\mathrm{NOCbl}$ and air at $1 \times 10^{-4}$ or $1 \times 10^{-3} \mathrm{M} \mathrm{Cbl}$ concentrations, which does not support the involvement of a second $\mathrm{Co}(\mathrm{III})$ complex in $\mathrm{NO}_{2} \mathrm{Cbl}$ formation. Note that this type of mechanism was initially proposed prior to more recent studies showing that $\mathrm{ONOOH}$ decomposes via $\mathrm{O}-\mathrm{O}$ bond homolysis to give ${ }^{\bullet} \mathrm{NO}_{2}$ and ${ }^{\bullet} \mathrm{OH} .{ }^{30}$

$\mathrm{NO}_{3}{ }^{-}$does not bind appreciably to the $\mathrm{Co}(\mathrm{III})$ center of cobalamins; ${ }^{28}$ therefore any $\mathrm{NO}_{3} \mathrm{Cbl}$ potentially formed from isomerization of $\mathrm{Co}-\mathrm{ONOO}^{-}$will decompose to $\mathrm{H}_{2} \mathrm{OCbl}^{+}$/ $\mathrm{HOCbl}$ and $\mathrm{NO}_{3}{ }^{-}$. Note that formation of the corresponding nitrato complex has been observed for the reaction of the nitrosyl cobaloxime complex $\mathrm{BCo}(\mathrm{DH})_{2} \mathrm{NO}(\mathrm{B}=$ base $)$ with $\mathrm{O}_{2}$ and for the reaction of other metal nitrosyl complexes with $\mathrm{O}_{2}{ }^{23}$ The observation of $\sim 37 \% \mathrm{NO}_{2} \mathrm{Cbl}$ suggests that like $\mathrm{ONOOH}$ and $\mathrm{ONOO}^{-}, \mathrm{Co}(\mathrm{III})$-bound $\mathrm{ONOO}^{-}$decomposes by $\mathrm{O}-\mathrm{O}$ homolysis. Ligand isomerization ultimately gives $\mathrm{H}_{2} \mathrm{OCbl}^{+} / \mathrm{HOCbl}$ after dissociation of the $\mathrm{ONO}_{2}^{-}$ligand, although it is not clear to us if this occurs via direct intramolecular rearrangement of the ligand in addition to $\mathrm{O}-$ $\mathrm{O}$ bond homolysis and recombination of the caged radical species. Others have reported that light can affect the products observed for the hydrolysis of a $\mathrm{Co}$ (III)-OONO ${ }^{-}$complex, $\left[\mathrm{Co}(\mathrm{CN})_{5}(\mathrm{OONO})\right]^{3-} .{ }^{61}$ Additionally Richter-Addo et al. ${ }^{60}$ found that the rate of the reaction of the picket fence porphyrin complex $[\mathrm{Fe}($ tpivpp $)(\mathrm{NO})]$ with air in $\mathrm{CHCl}_{3}$ solution is enhanced by light. A control experiment in the absence of regular laboratory light showed that light has no effect on the observed product ratio for our system, Supporting Information, Figure S17.

It occurred to us that as for other cob(III)alamins with inorganic ligands bound at the $\beta$-axial site, $\mathrm{Co}(\mathrm{III})-\mathrm{ONOO}^{-}$is in equilibrium with $\mathrm{H}_{2} \mathrm{OCbl}^{+} / \mathrm{HOCbl}$ plus $\mathrm{ONOO}(\mathrm{H})$ at $\mathrm{pH}$ 7.4, and that decomposition of the intermediate may therefore occur via hydrolysis of Co-ONOO${ }^{-}$. However, a comparison of the observed rate constants for the reaction between NOCbl and $\mathrm{O}_{2}$ at $\mathrm{pH} 10.40\left(k_{\mathrm{obs}}=0.05-0.35 \mathrm{~s}^{-1}\right.$, Supporting Information, Figure S2) and the observed rate constant for ONOO $(\mathrm{H})$ decomposition at $\mathrm{pH} 10.40\left(k_{\mathrm{obs}}=4.68 \times 10^{-4} \mathrm{~s}^{-1}\right.$; Supporting Information, Figure S18) makes it clear that decomposition via this pathway is not occurring. Given that $\mathrm{ONOO}^{-}$is so stable in aqueous solution, ${ }^{62}$ it is likely that the metal center substitutes for the proton of $\mathrm{ONOOH}$, to assist in the decomposition of $\mathrm{Co}$ (III)-bound peroxynitrite. ${ }^{50,63}$ However, note that the proton of $\mathrm{ONOOH}$ is located on an $\mathrm{O}$ atom, whereas it is likely that $\mathrm{N}$-bound $\mathrm{Co}(\mathrm{III})-\mathrm{N}(\mathrm{O}) \mathrm{OO}^{-}$is initially formed. Whether or not this latter complex isomerizes to $O$ bound $\mathrm{Co}(\mathrm{III})-\mathrm{OONO}^{-}$prior to undergoing $\mathrm{O}-\mathrm{O}$ bond homolysis of the ligand to give ${ }^{\bullet} \mathrm{NO}_{2}$ and ${ }^{\bullet} \mathrm{OH}$ is not known.

Phenol and tyrosine are established trapping agents for ${ }^{\circ} \mathrm{NO}_{2}$ and ${ }^{\bullet} \mathrm{OH}$. Aerial oxidation of $\mathrm{NOCbl}$ in the presence of phenol $(0.10 \mathrm{M})$ gave nitrated phenol products $(<1 \%)$, providing evidence for a ${ }^{\bullet} \mathrm{NO}_{2}$ intermediate. In the presence of a Tyr trap $\mathrm{OH}-\mathrm{Tyr}$ was detected, consistent with formation of a ${ }^{\bullet} \mathrm{OH}$ intermediate. HPLC and mass spectrometry also provided

Scheme 4. Proposed Reaction Pathways for the Reaction between NOCbl and $\mathrm{O}_{2}$

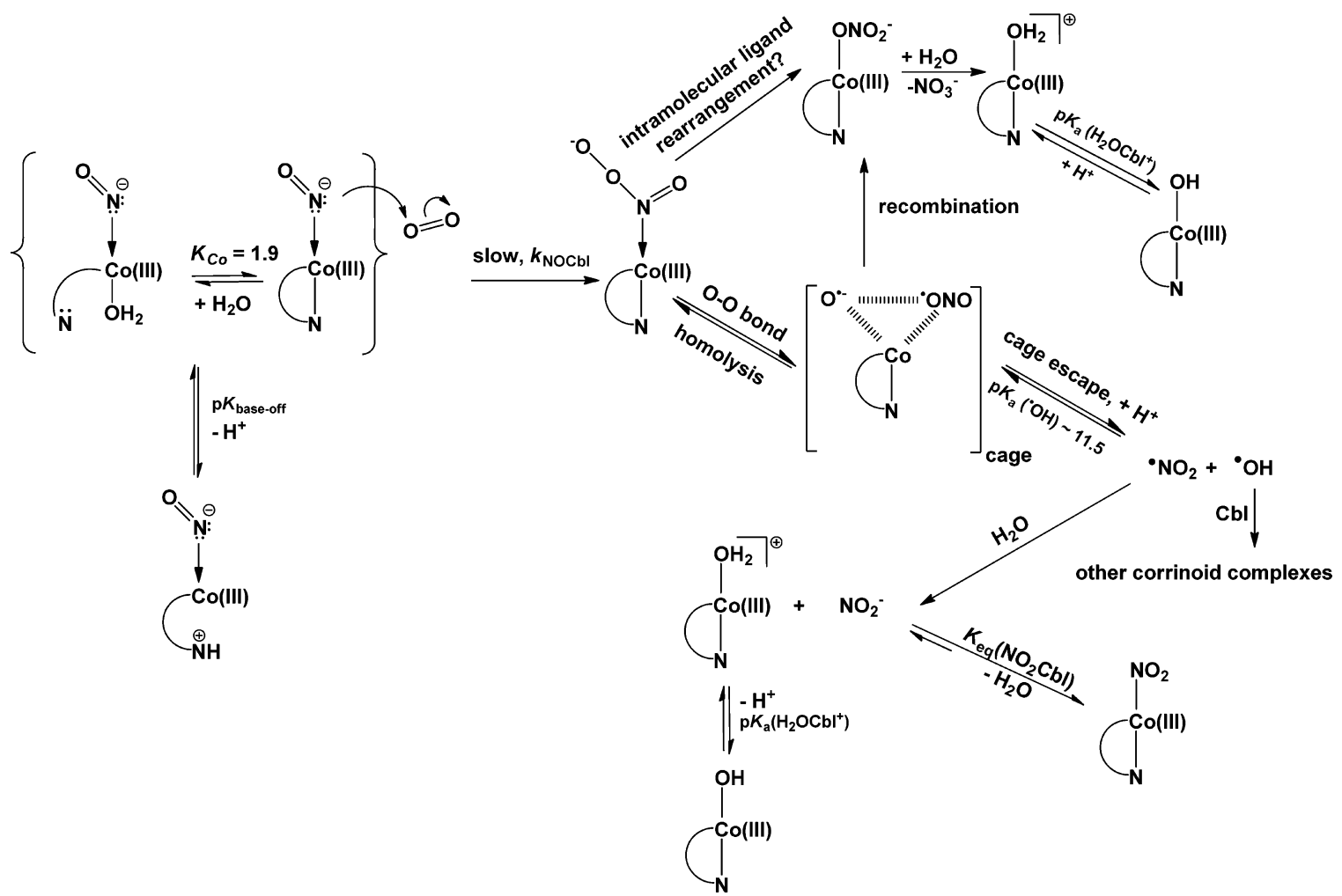


evidence for formation of a small amount of a corrinoid species with two less $\mathrm{H}$ atoms than $\mathrm{Cbl}$, consistent with attack by ${ }^{\bullet} \mathrm{OH}$ on the corrin ring.

Scheme 4 summarizes the proposed reaction pathways for the reaction between $\mathrm{NOCbl}$ and $\mathrm{O}_{2}$. In this scheme the ratedetermining reaction of $\mathrm{NOCbl}$ with $\mathrm{O}_{2}$ to form an $\mathrm{N}$-bound peroxynitritocobalamin intermediate is followed by $\mathrm{O}-\mathrm{O}$ bond homolysis of the $\mathrm{Co}(\mathrm{III})$-bound peroxynitrite ligand and ligand isomerization. It is not clear to us whether ligand isomerization occurs via direct intramolecular ligand rearrangement in addition to $\mathrm{O}-\mathrm{O}$ bond homolysis followed by radical recombination. In any event, ligand isomerization leads to formation of nitratocobalamin $\left(\mathrm{NO}_{3} \mathrm{Cbl}\right)$, which rapidly hydrolyzes to $\mathrm{H}_{2} \mathrm{OCbl}^{+}{ }^{28} \mathrm{O}-\mathrm{O}$ bond homolysis results in the formation of caged ${ }^{\bullet} \mathrm{NO}_{2}$ and ${ }^{\bullet} \mathrm{OH}$. Theoretical studies show that $\mathrm{ONOO}^{-}$decomposes to ${ }^{\circ} \mathrm{NO}_{2}$ and ${ }^{\bullet} \mathrm{O}^{-} ;{ }^{64}$ the latter is rapidly protonated to form ${ }^{\circ} \mathrm{OH}\left(\mathrm{pK}_{\mathrm{a}}\left({ }^{\bullet} \mathrm{OH}\right) \sim 11.5^{65}\right)$. Upon release from the cage ${ }^{\bullet} \mathrm{NO}_{2}$ reacts rapidly with itself and $\mathrm{H}_{2} \mathrm{O}$ to produce $\mathrm{NO}_{2}{ }^{-55,66}$ which then substitutes the $\beta$-axial $\mathrm{H}_{2} \mathrm{O}$ ligand of $\mathrm{H}_{2} \mathrm{OCbl}^{+}$to form $\mathrm{NO}_{2} \mathrm{Cbl}$. The yields of the phenol and Tyr - trapped ${ }^{\bullet} \mathrm{NO}_{2}$ and ${ }^{\bullet} \mathrm{OH}$ products $(<1 \%)$ are considerably less than those observed for spontaneous $\mathrm{ONOOH}$ decomposition under the neutral $\mathrm{pH}$ conditions of this study, suggesting that $\mathrm{Cbl}$ can also trap these species. In support of this, a novel corrinoid complex is observed in the HPLC chromatogram with a mass which is 2 units smaller than $\mathrm{Cbl}$ itself, consistent with scavenging of ${ }^{\bullet} \mathrm{OH}$ by the corrin ring. - $\mathrm{OH}$ could potentially also react with the corrin ring of the $\mathrm{Cbl}$ within the caged complex.

\section{CONCLUSIONS}

Kinetic and mechanistic studies on the reaction between $\mathrm{NOCbl}$ and $\mathrm{O}_{2}$ show that the reaction is rapid, and proceeds via an associative mechanism with the formation of a peroxynitritocob(III)alamin intermediate, $\mathrm{Co}(\mathrm{III})-\mathrm{N}(\mathrm{O}) \mathrm{OO}^{-}$. The intermediate undergoes $\mathrm{O}-\mathrm{O}$ bond homolysis and ligand isomerization to ultimately yield $\mathrm{NO}_{2} \mathrm{Cbl}$ and $\mathrm{H}_{2} \mathrm{OCbl}^{+}$/ $\mathrm{HOCbl}$, respectively. Ligand isomerization may potentially occur independent of $\mathrm{O}-\mathrm{O}$ bond homolysis. Formation of small amounts of ${ }^{\bullet} \mathrm{OH}$ and ${ }^{\bullet} \mathrm{NO}_{2}$ intermediates is demonstrated using phenol and tyrosine radical traps and ESI-MS characterization of a corrinoid complex with $2 \mathrm{H}$ less than the $\mathrm{Cbl}$ unit. This study gives a detailed mechanistic analysis of the seemingly simple reaction between the biologically important cobalamin NOCbl and oxygen. The oxygen concentration in cells varies from 4 to $40 \mu \mathrm{M} .^{67}$ Assuming a concentration of 20 $\mu \mathrm{M}$, the half-life for the reaction of NOCbl with $\mathrm{O}_{2}$ is $\sim 1 \mathrm{~min}$ $\left(25^{\circ} \mathrm{C}\right)$. In air the half-life for NOCbl decomposition is $\sim 5 \mathrm{~s}$.

\section{ASSOCIATED CONTENT}

\section{S Supporting Information}

Additional kinetic data, ${ }^{1} \mathrm{H}$ NMR spectra, and HPLC and ESIMS chromatograms; Figures S1-S18. This material is available free of charge via the Internet at http://pubs.acs.org.

\section{AUTHOR INFORMATION}

\section{Corresponding Author}

*E-mail: nbrasch@kent.edu.

\section{Notes}

The authors declare no competing financial interest.

\section{ACKNOWLEDGMENTS}

The authors gratefully acknowledge the assistance of Dr. Donald L. Dick (Department of Chemistry, Colorado State University, CO, U.S.A.) with mass spectrometry experiments. This material is based upon work supported by the U.S. National Science Foundation under Grant CHE-0848397.

\section{REFERENCES}

(1) Dennis, J. S. Biochim. Biophys. Acta 1999, 1411, 217.

(2) Ignarro, L. J.; Cirino, G.; Casini, A.; Napoli, C. J. Cardiovasc. Pharmacol. 1999, 34, 879.

(3) Bian, K.; Murad, F. Front. Biosci. 2003, 8, d264.

(4) Hassanin, H. A.; Hannibal, L.; Jacobsen, D. W.; Brown, K. L.; Marques, H. M.; Brasch, N. E. Dalton Trans. 2009, 424.

(5) Nicolaou, A.; Kenyon, S. H.; Gibbons, J. M.; Ast, T.; Gibbons, W. A. Eur. J. Clin. Invest. 1996, 26, 167.

(6) Kambo, A.; Sharma, V. S.; Casteel, D. E.; Woods, V. L.; Pilz, R. B.; Boss, G. R. J. Biol. Chem. 2005, 280, 10073.

(7) Brouwer, M.; Chamulitrat, W.; Ferruzzi, G.; Sauls, D.; Weinberg, J. Blood 1996, 88, 1857.

(8) Carmen, W. Med. Hypotheses 2006, 67, 124.

(9) Padovani, D.; Banerjee, R. Biochemistry 2006, 45, 9300.

(10) Wolak, M.; Zahl, A.; Schneppensieper, T.; Stochel, G.; van Eldik, R. J. Am. Chem. Soc. 2001, 123, 9780.

(11) Zheng, D.; Birke, R. L. J. Am. Chem. Soc. 2001, 123, 4637.

(12) Wheatley, C. J. Nutr. Environ. Med. 2007, 16, 181.

(13) Jiang, F.; Li, C. G.; Rand, M. J. Eur. J. Pharmacol. 1997, 340, 181.

(14) Rand, M. J.; Li, C. G. Eur. J. Pharmacol. 1993, 241, 249.

(15) Greenberg, S. S.; Xie, J.; Zatarain, J. M.; Kapusta, D. R.; Miller, M. J. J. Pharmacol. Exp. Ther. 1995, 273, 257.

(16) Bauer, J. A.; Lupica, J. A.; Schmidt, H.; Morrison, B. H.; Haney, R. M.; Masci, R. K.; Lee, R. M.; DiDonato, J. A.; Lindner, D. J. PLoS ONE 2007, 2, e1313.

(17) Wolak, M.; Stochel, G.; van Eldik, R. Inorg. Chem. 2005, 45, 1367.

(18) Hannibal, L.; Smith, C. A.; Jacobsen, D. W.; Brasch, N. E. Angew. Chem., Int. Ed. 2007, 46, 5140.

(19) Weil, M.; Abeles, R.; Nachmany, A.; Gold, V.; Michael, E. Cell Death Differ. 2004, 11, 361.

(20) Nicolaou, A.; Waterfiesd, C. J.; Kenyon, S. H.; Gibbons, W. A. Eur. J. Biochem. 1997, 244, 876.

(21) Danishpajooh, I. O.; Gudi, T.; Chen, Y.; Kharitonov, V. G.; Sharma, V. S.; Boss, G. R. J. Biol. Chem. 2001, 276, 27296.

(22) Suarez-Moreira, E.; Hannibal, L.; Smith, C. A.; Chavez, R. A.; Jacobsen, D. W.; Brasch, N. E. Dalton Trans. 2006, 5269.

(23) Trogler, W. C.; Marzilli, L. G. Inorg. Chem. 1974, 13, 1008.

(24) Vlasova, E. A.; Hessenauer-Ilicheva, N.; Salnikov, D. S.; Kudrik, E. V.; Makarov, S. V.; van Eldik, R. Dalton Trans. 2009, 10541.

(25) Barker, H. A.; Smyth, R. D.; Weissbach, H.; Toohey, J. I.; Ladd, J. N.; Volcani, B. E. J. Biol. Chem. 1960, 235, 480.

(26) Pinto, E.; Petissca, C.; Amaro, L. F.; Pinho, O.; Ferreira, I. M. P. L. V. O. J. Liq. Chromatogr. Relat. Technol. 2010, 33, 591.

(27) Ferreira, I. M. P. L. V. O.; Silva, S. Talanta 2008, 74, 1598.

(28) Pratt, J. M. Inorganic Chemistry of Vitamin $B_{12}$; Academic Press: New York, 1972; p 280.

(29) Brasch, N. E.; Finke, R. G. J. Inorg. Biochem. 1999, 73, 215.

(30) Clarkson, S. G.; Basolo, F. Inorg. Chem. 1973, 12, 1528.

(31) Ford, P. C.; Lorkovic, I. M. Chem. Rev. 2002, 102, 993.

(32) Herold, S.; Koppenol, W. H. Coord. Chem. Rev. 2005, 249, 499.

(33) Frech, C. M.; Blacque, O.; Schmalle, H. W.; Berke, H. Dalton Trans. 2006, 4590

(34) Arnold, E. V.; Bohle, D. S. Methods Enzymol. 1996, 269, 41.

(35) Park, G. Y.; Deepalatha, S.; Puiu, S. C.; Lee, D.-H.; Mondal, B.; Narducci, S. A. A.; del Rio, D.; Pau, M. Y. M.; Solomon, E. I.; Karlin, K. D. J. Biol. Inorg. Chem. 2009, 14, 1301.

(36) Herold, S.; Exner, M.; Nauser, T. Biochemistry 2001, 40, 3385.

(37) Nemes, A.; Pestovsky, O.; Bakac, A. J. Am. Chem. Soc. 2001, 124, 421. 
(38) Wick, P. K.; Kissner, R.; Koppenol, W. H. Helv. Chim. Acta

2000, 83, 748.

(39) Ramezanian, M. S.; Padmaja, S.; Koppenol, W. H. Chem. Res. Toxicol. 1996, 9, 232.

(40) Mukherjee, R.; Brasch, N. E. Chem.-Eur. J. 2011, 17, 11805.

(41) Beckman, J. S. Chem. Res. Toxicol. 1996, 9, 836.

(42) Pietraforte, D.; Salzano, A. M.; Marino, G.; Minetti, M. Amino Acids 2003, 25, 341.

(43) Santos, C. X. C.; Bonini, M. G.; Augusto, O. Arch. Biochem. Biophys. 2000, 377, 146.

(44) Lymar, S. V.; Jiang, Q.; Hurst, J. K. Biochemistry 1996, 35, 7855.

(45) Bartesaghi, S.; Valez, V.; Trujillo, M.; Peluffo, G.; Romero, N.;

Zhang, H.; Kalyanaraman, B.; Radi, R. Biochemistry 2006, 45, 6813.

(46) Bonnett, R.; Cannon, J. R.; Clark, V. M.; Johnson, A. W.; Parker,

L. F. J.; Smith, E. L.; Todd, A. J. Chem. Soc. 1957, 1158.

(47) Bonnett, R. Chem. Rev. 1963, 63, 573.

(48) Reference 28, p 193.

(49) Matthews, J. H. Blood 1997, 89, 4600.

(50) Goldstein, S.; Lind, J.; Merényi, G. Chem. Rev. 2005, 105, 2457.

(51) Kurtikyan, T. S.; Eksuzyan, S. R.; Hayrapetyan, V. A.; Martirosyan, G. G.; Hovhannisyan, G. S.; Goodwin, J. A. J. Am. Chem. Soc. 2012, 134, 13861.

(52) Maiti, D.; Lee, D.-H.; Narducci, S. A. A.; Pau, M. Y. M.; Solomon, E. I.; Gaoutchenova, K.; Sundermeyer, J.; Karlin, K. D. J. Am. Chem. Soc. 2008, 130, 6700.

(53) Kalita, A.; Kumar, P.; Mondal, B. Chem. Commun. 2012, 48, 4636.

(54) Szabo, C.; Ischiropoulos, H.; Radi, R. Nat. Rev. Drug Discovery 2007, 6, 662.

(55) Goldstein, S.; Merényi, G. In Methods in Enzymology; Robert, K. P., Ed.; Academic Press: New York, 2008; Vol. 436, p 49.

(56) Koppenol, W. H.; Bounds, P. L.; Nauser, T.; Kissner, R.; Rueegger, H. Dalton Trans. 2012, 41, 13779.

(57) Koppenol, W. H.; Moreno, J. J.; Pryor, W. A.; Ischiropoulos, H.; Beckman, J. S. Chem. Res. Toxicol. 1992, 5, 834.

(58) Lippard, S. J.; Berg, J. M. Principles Bioinorganic Chemistry; University Science Books: Mill Valley, CA, 1994.

(59) Ishii, K.; Aoki, K. Anal. Chem. 1983, 55, 604.

(60) Cheng, L.; Powell, D. R.; Khan, M. A.; Richter-Addo, G. B. Chem. Commun. 2000, 2301.

(61) Wick, P. K.; Kissner, R.; Koppenol, W. H. Helv. Chim. Acta 2001, 84, 3057.

(62) Al-Ajlouni, A. M.; Gould, E. S. Inorg. Chem. 1996, 35, 7892.

(63) Herold, S. FEBS Lett. 1999, 443, 81.

(64) Merényi, G.; Lind, J.; Goldstein, S.; Czapski, G. J. Phys. Chem. A 1999, 103, 5685.

(65) Poskrebyshev, G. A.; Neta, P.; Huie, R. E. J. Phys. Chem. A 2002, 106, 11488.

(66) Merényi, G.; Lind, J. Chem. Res. Toxicol. 1998, 11, 243.

(67) Fandrey, J.; Gorr, T. A.; Gassmann, M. Cardiovasc. Res. 2006, 71,642 . 